I N T ER N ATIONAL MONETARY FUND

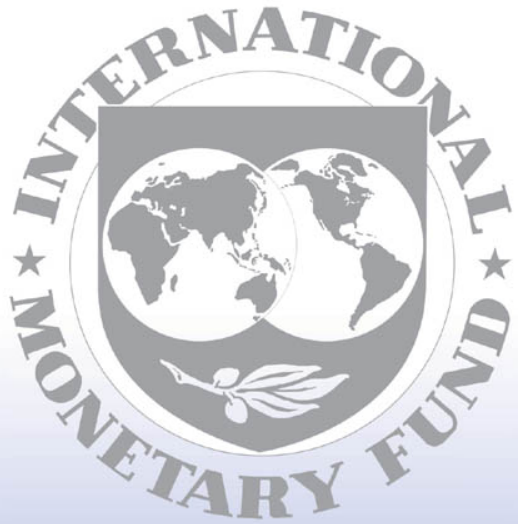

Staff

Country

Reports 


\section{Hungary: First Post-Program Monitoring Discussions}

The following documents have been released and are included in this package:

- $\quad$ The staff report, prepared by a staff team of the IMF, following discussions that ended on April 11, 2011, with the officials of Hungary on economic developments and policies. Based on information available at the time of these discussions, the staff report was completed on May 20, 2011. The views expressed in the staff report are those of the staff team and do not necessarily reflect the views of the Executive Board of the IMF.

- $\quad$ A supplement to the staff report.

- $\quad$ A staff statement.

- $\quad$ A Public Information Notice (PIN).

The document listed below will be separately released:

Ex Post Evaluation of Exceptional Access Under the 2008 Stand-By Arrangement

The policy of publication of staff reports and other documents allows for the deletion of market-sensitive information.

\section{International Monetary Fund Washington, D.C.}


INTERNATIONAL MONETARY FUND

HUNGARY

First Post-Program Monitoring Discussions

Prepared by the European Department in Consultation with Other Departments

Approved by Anne-Marie Gulde-Wolf and Lorenzo Giorgianni

May 20, 2011

\section{EXECUTIVE SUMMARY}

Context and past surveillance: A modest export-driven recovery is underway and financial market sentiment has recently improved. However, significant vulnerabilities remain, notably high public and external debt, a demanding sovereign amortization schedule, and large currency mismatches. During the Board meeting for the 2010 Article IV Consultation in January 2011, Directors expressed concern about the authorities' policy response to these challenges, which relied on large tax cuts financed by temporary fiscal measures including sectoral levies and the transfer of the defined-contribution private pension pillar to the state. They called for a comprehensive structural fiscal adjustment program to restore medium-term fiscal stability, as well as measures to normalize credit conditions, especially in the mortgage market.

Authorities' strategy: The authorities recently announced a structural reform program, the Szell Kalman Plan, which aims to restore fiscal sustainability and investor confidence. Cumulatively, the package targets 3 percent of GDP in fiscal consolidation in 2011-13, with the bulk of measures on the expenditure side (cuts in social benefits, pension eligibility, health care, education, and streamlining public administration). Additional measures, including a one-year extension of the bank levy, aim at keeping the deficit below 3 percent of GDP from 2012, as agreed with the EU. The government is also nearing completion on an agreement with banks to address ongoing stress in real estate portfolios. In view of lower inflation prospects and risks spreads, the main policy rate has been put on hold.

Staff's views: The broad direction of reforms outlined in the Szell Kalman Plan is appropriate. If taken at face value, it would help to restore debt sustainability and eventually support growth. But implementation risks loom large, suggesting that critical details should be spelled out and enacted quickly. To improve the durability of measures, staff recommended to focus more on reducing overstaffing in local governments and state-owned enterprises, means-testing social benefits (rather than across-the-board cuts), and quickly removing distortive sectoral levies. The government's attempt to find cooperative solutions with the banking sector is welcome, but support schemes for distressed mortgage holders should be transparent, targeted at social objectives, and minimize fiscal cost and moral hazard. Official reserve coverage could be increased to provide a safety cushion in view of large forthcoming external financing needs in the public and banking sectors.

Mission dates and team: April 4-11, 2011. Messrs. Rosenberg (head), Gottlieb, Wiegand, (all EUR), Guerson (FAD), Noah and Saenz (SPR), and Ms. Ivaschenko (Resident Representative) met with Prime Minister Orbán, Minister for National Economy Matolcsy, Central Bank Governor Simor, other government agencies and banks. Mr. Abel (OED) participated in some of the mission's discussions. The team worked closely with the EC's overlapping first post-program surveillance mission. 
Contents

Page

Executive Summary

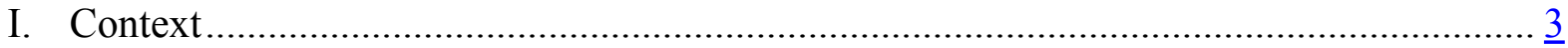

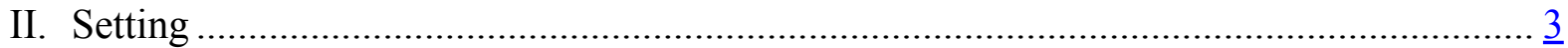

A. Recent Economic and Financial Developments...................................................... $\underline{3}$

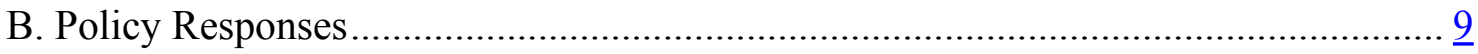

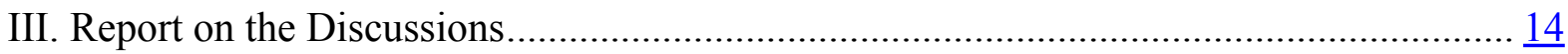

A. Macroeconomic Outlook and Risks................................................................. 14

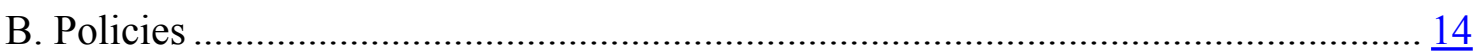

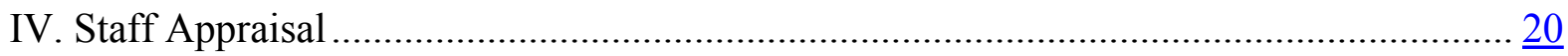

Figure

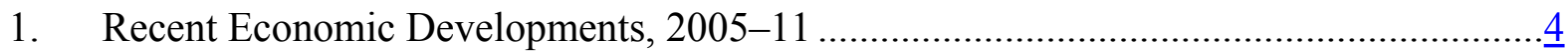

Tables

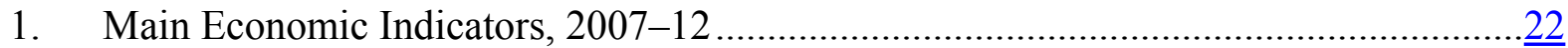

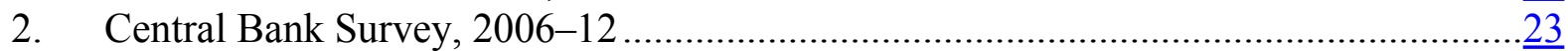

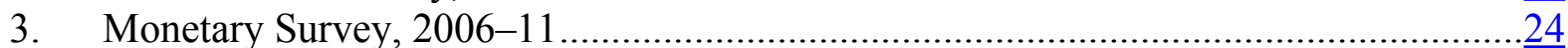

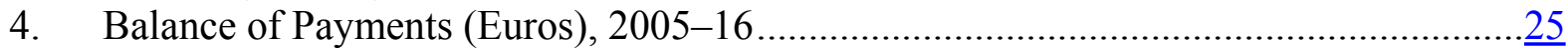

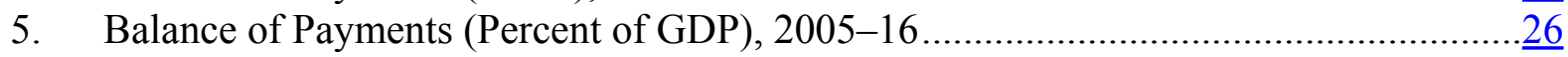

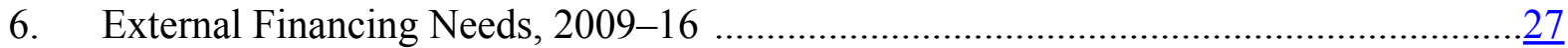

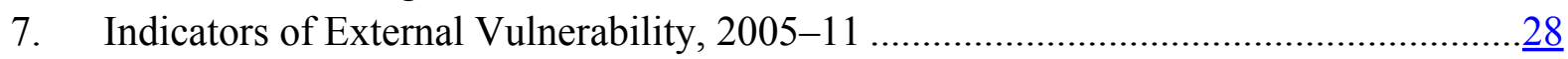

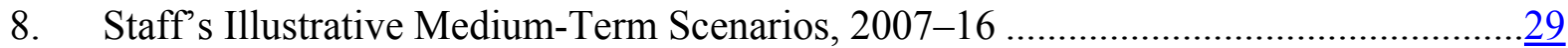

9. Consolidated General Government, 2007-12 ……...............................................

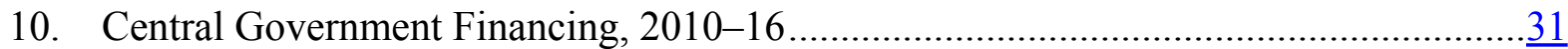

11. Financial Soundness Indicators for the Banking Sector, 2008-10 …..........................32

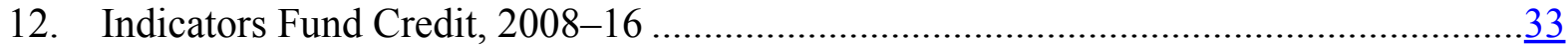

Boxes

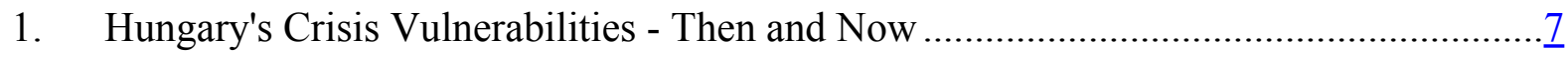

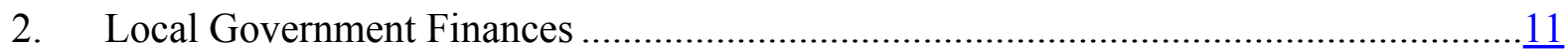

3. Measures in the Scheme to Support Mortgage Debtors and an Efficient Functioning

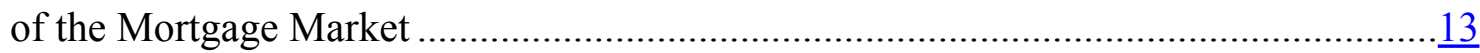

4. Alternative Metrics of Reserve Coverage .................................................................19

Appendices Figures

1. Public Debt Sustainability: Bound Tests, ............................................................

2. External Debt Sustainability: Bound Tests .............................................................

Appendices Tables

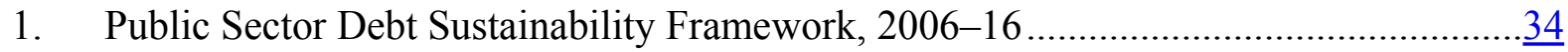

2. External Debt Sustainability: Framework, 2006-16 …................................................. 


\section{Context}

1. In recent months, the authorities have announced changes in their policy stance. The new policy mix, which has yet to be implemented, introduces structural fiscal adjustment to reduce high public debt as well as progress in addressing ongoing stress in banks' real estate portfolios. The recent announcements contrast with the authorities' approach only a few months ago, when they emphasized that rapid tax cut-induced growth, rather than policy adjustment, would be adequate to address outstanding vulnerabilities - a strategy that at the time raised concerns at the Fund (in the 2010 Article IV consultation) ${ }^{1}$ and the European Commission (EC) as well as in financial markets.

\section{The Post-Program Monitoring (PPM) discussions focused on the new policy} stance and how it would contribute to Hungary's capacity to meet obligations to the Fund falling due in 2012-13. The next six to twelve months are a critical period in this respect, as in the next three years, Hungary faces both a difficult external amortization schedule and parliamentary elections. With the ruling Fidesz party continuing to command a substantial legislative majority, the capacity to implement reforms is adequate but political will remains uncertain. In this context, the authorities face a short window of opportunity to implement key reforms which strengthen Hungary's fiscal and external position.

\section{Setting}

\section{A. Recent Economic and Financial Developments}

3. The recovery in the Hungarian economy remains weak due to a lack of domestic demand. After falling 14 percent in real terms in the 12 months to mid-2009, domestic demand has remained essentially flat. Still high unemployment, muted wage growth, falling consumer confidence, and stagnant credit are weighing on consumption. Meanwhile, fixed investment continues to decline amid considerable idle capacity, bottlenecks to credit supply, limited final demand, and an uncertain business environment. Recent data underscore concerns about the recovery: retail sales growth remains flat in early 2011 while the rate of decline in fixed investment actually accelerated in Q4 2010. Such weak demand has kept a lid on underlying inflationary pressures, while private real sector wage growth remained at historic lows. (See Figure 1)

\footnotetext{
${ }^{1}$ See IMF country report No. 11/35.
} 
Figure 1. Hungary: Recent Economic Developments, 2005-11
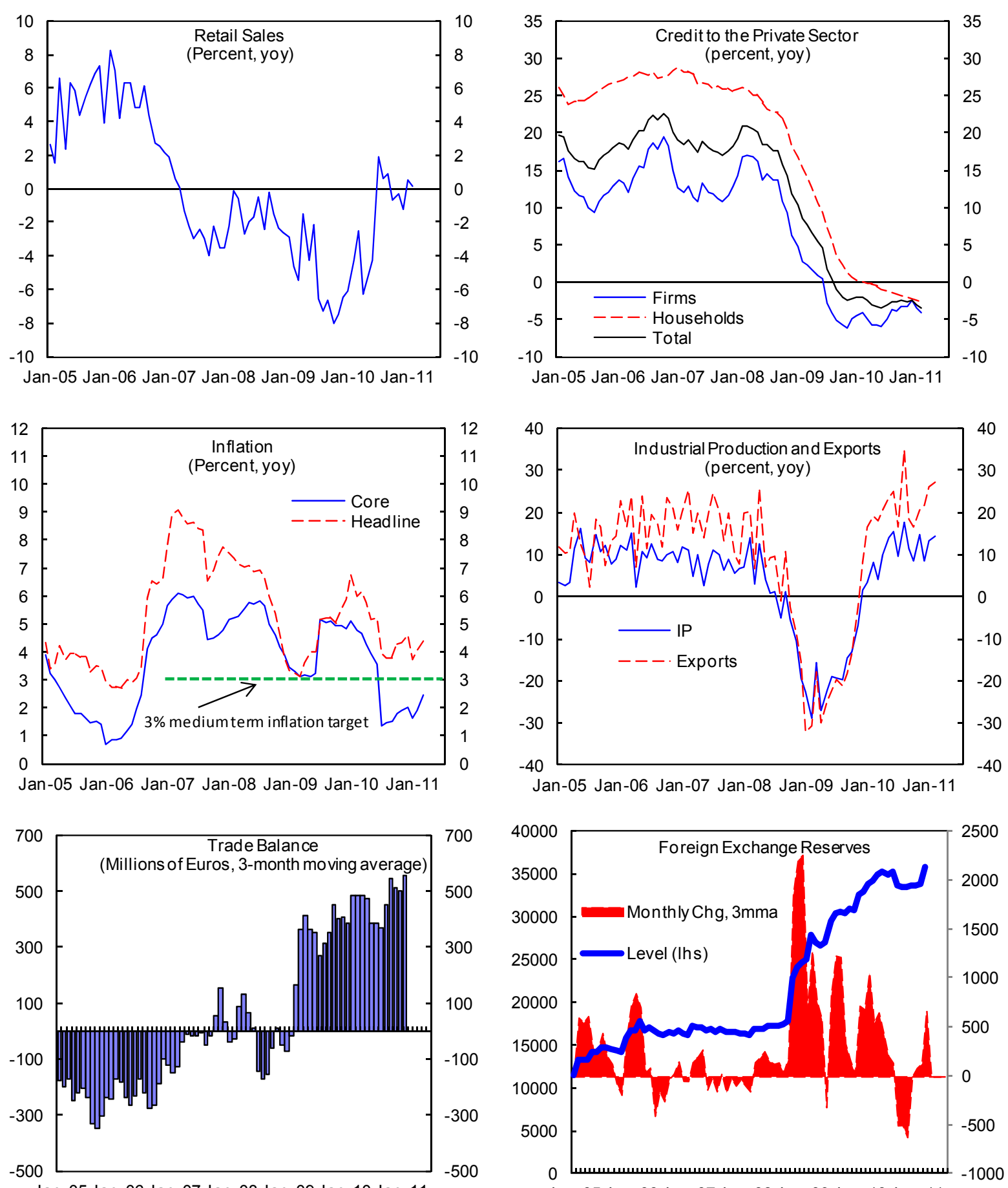

700
500
300
100
-100
-300
-500

Jan-05 Jan-06 Jan-07 Jan-08 Jan-09 Jan-10 Jan-11

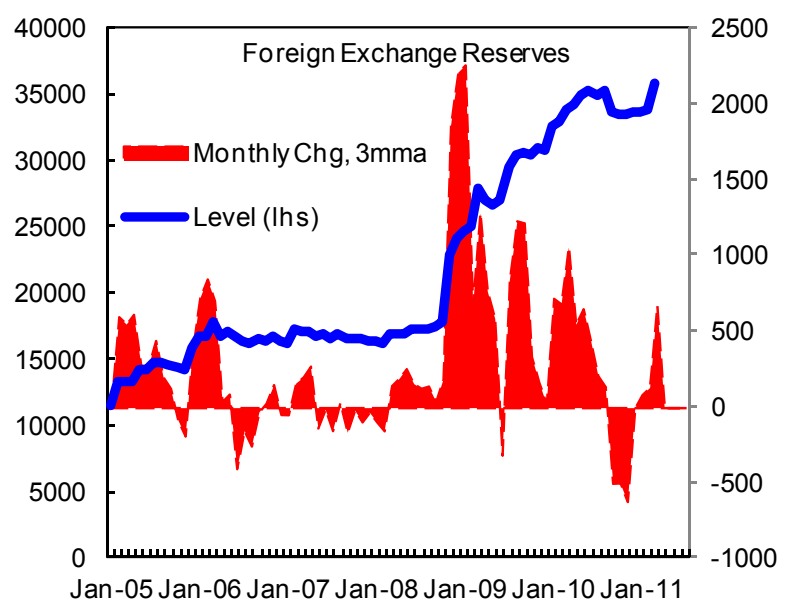

Source: Haver. 
4. Meeting budgetary targets remains a challenge. The 2010 general government deficit of 4.3 percent of GDP (ESA terms) exceeded its target by $1 / 2$ percentage pointmainly at the local government level — despite a series of ad hoc corrective measures late in the year. This slippage implied a primary structural weakening of $13 / 4$ percent of GDP in 2010, undoing much of the adjustment achieved during the 2008-10 Stand-By Arrangement (see the forthcoming Ex-Post Evaluation report). Poor budget performance continued into the start of 2011 where the first quarter central government cash deficit has already exceeded the government's initial annual target, largely because revenues fell short of optimistic expectations.

\section{The one bright spot has been the external sector, which continues to drive} economic growth. The current account improved from a 7.3 percent of GDP deficit in 2008 to a 2.1 percent of GDP surplus in 2010. Though part of the adjustment is due to the impact of the slump in domestic demand on imports, exports remain the key driver of adjustment, rising 14 percent in 2010 amid strong demand from Germany. ${ }^{2}$ Exports strengthened further in early 2011 with February posting the largest trade surplus on record. Meanwhile, after the sharp outflows during the crisis, the capital and financial accounts have begun to normalize with rising portfolio investment compensating for continued deleveraging by parent banks. There has, however, also been a marked increase in negative errors and omissions to more than 2 percent of GDP in 2010, in line with similar developments elsewhere in the region. ${ }^{3}$ Gross international reserves are increasing, largely due to a pick-up in EU transfers and, more recently, successful sovereign debt placements of some $€ 4$ billion, which are deposited at the central bank (MNB).

\section{While the banking system has been resilient, a key short-term risk to credit} quality remains the strength of the Swiss franc (CHF). After-tax profit dropped from $91 / 4$ percent in 2009 (return on equity) to $1 \frac{1 / 4}{4}$ percent in 2010 on a consolidated basis, with the decline largely reflecting the introduction of the bank levy as well as further provisioning. Capital adequacy for the banking system as a whole improved marginally to 14.1 percent while non-performing loans again increased, reaching 9.1 percent, but at a slower pace than in previous periods. A key issue is that two-thirds of existing household loans are denominated in CHF which remains some 20-30 percent stronger against the forint than long-term averages. As a result, there are continuing concerns about households' repayment and spending capacity as well as implications for banks' balance sheets.

\section{Household and corporate lending remain subdued, further limiting banks'} earnings. A mix of demand and supply factors continue to undermine credit growth

\footnotetext{
${ }^{2}$ The rise in manufactured goods prices largely offset the negative impact of higher energy prices on Hungary's terms of trade.

${ }^{3}$ The authorities attribute this increase in errors and omissions to misreporting of trade flows and difficulties to accurately record capital transfer between households.
} 
including the weak economy, an uncertain business environment, and the ongoing ban on foreclosures. Amid such a weak environment for credit growth and earnings more broadly, banks have moved to further limit funding costs by selling forint assets (MNB bills), converting this liquidity into Foreign Exchange (FX) in the largely short term FX swap market, and repaying more expensive long-term foreign loans, both from parents and the wholesale market. As a result, the share of banks' on- and off-balance sheet foreign funding that is short term has risen.

8. Despite the uncertain economic outlook, Hungarian asset prices have improved.

Since early 2011, risk spreads have tightened roughly $150 \mathrm{bps}$ in absolute terms

(see Text Figure 1) as the anticipation of fiscal reforms coincided with a general increase in portfolio investors' appetite for assets in the region. CDS spreads have also dropped almost $100 \mathrm{bps}$ relative to new member state peers, but remain well above those posted before the change in government in April 2010. This persistent relative risk premium suggests lingering market concern about how the authorities will address outstanding vulnerabilities regarding public and external debt, official reserve coverage, and currency mismatches. In currency markets, the forint has strengthened since the mid-2010 sell-off. Nevertheless, CGER estimates still view the currency as broadly in line with fundamentals; in fact, when measured using unit labor costs, the real effective exchange rate is roughly 20 percent more competitive than before the crisis.

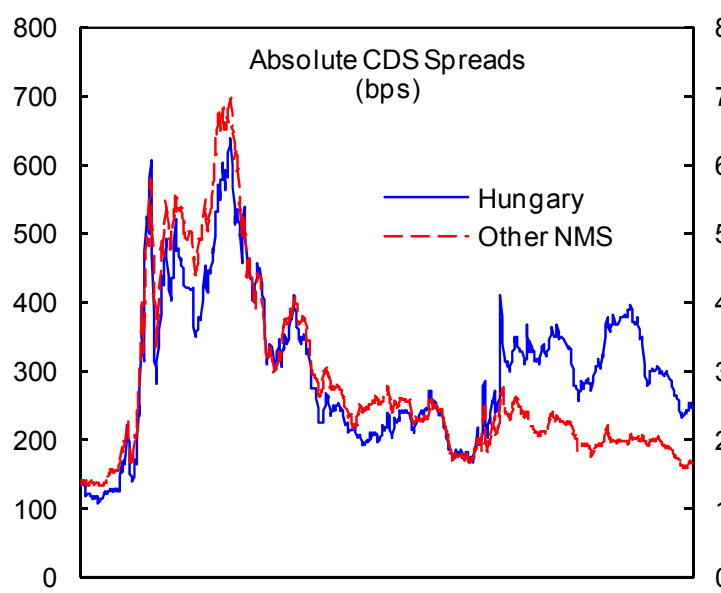

Jun-08 Dec-08 Jun-09 Nov-09 May-10 Oct-10 Apr-11

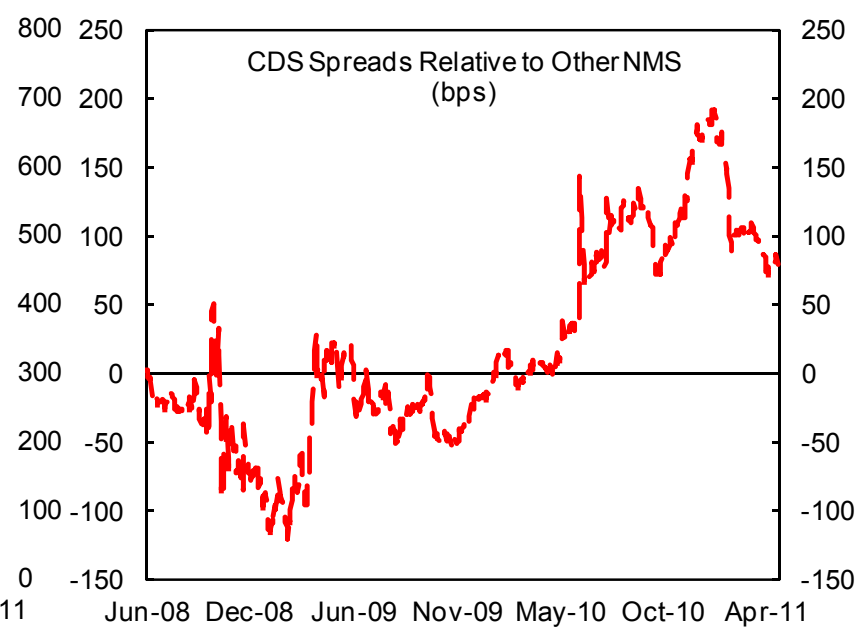

Jun-08 Dec-08 Jun-09 Nov-09 May-10 Oct-10 Apr-11

Source: Bloomberg. 


\section{Box 1. Hungary's Crisis Vulnerabilities—Then and Now}

\section{Hungary's economy is known for two key underlying vulnerabilities:}

- $\quad$ First, Hungary has high external debt of 140 percent of GDP, largely held by banks and the government. Banks' foreign debt, at 36 percent of GDP, includes substantial borrowing from parents (two thirds of total). Meanwhile, the public sector has external debt of 53 percent of GDP, of which about 20 percent is non-residents holdings of local currency debt.

- $\quad$ Second, both households and banks have substantial currency mismatches. Household balance sheets are short foreign currency as they have borrowed heavily in Swiss francs to finance mortgages and consumption. By contrast, banks hold more FX assets than they generate in FX funding and are thus long foreign currency. While households have limited ability to hedge this exposure, banks cover almost 90 percent of their open position with off balance sheet FX swaps and other instruments.

\section{Both vulnerabilities played key roles in the crisis:}

- In late 2008, non-residents started a sharp sell-off in the local government bond market, which in turn triggered a large depreciation in the currency.

- $\quad$ Furthermore, the fall in foreigners' demand for Hungary exposure caused domestic banks without a parent to lose access to needed wholesale funding.

- Meanwhile, the forint weakness created strains in the FX swap market: suddenly, banks faced difficulty in rolling over their swaps and faced margin calls on their remaining swaps.

- $\quad$ As a result, the banking system as a whole faced dramatic pressure on liquid assets though banks with a parent were able to stabilize their liquidity by increasing borrowing abroad.

Two and a half-years later, Hungary is better placed to withstand similar shocks, including possible spillovers from problems in the European banking system. The MNB now has well-tested policy instruments to react to funding strains such as the FX swap facility. Furthermore, buffers are now much larger (see panel on subsequent page):

- $\quad$ Banks have vastly increased their holdings of liquid assets which fell sharply in late 2008. Admittedly, in recent quarters, liquid assets have started to moderate again (Chart 1).

- $\quad$ Furthermore, the $\boldsymbol{F X}$ reserves of the government are roughly double their pre-crisis levels, even if still modest by some metrics (Box 4) and due in part to outstanding liabilities to the IMF (Chart 2)

However, Hungary remains exposed to several underlying vulnerabilities:

- $\quad$ Despite the ban on new lending in FX, Hungary still faces large currency mismatch on stocks. Given the relatively long maturity of FX loans, this is unlikely to change quickly (Chart 3).

- While there has been some reduction in external liabilities in recent quarters, banks' foreign borrowing remains large and the share that is short term has been rising (Chart 4).

- While lower than during the crisis, banks' dependence on the FX swap market remains somewhat above pre-crisis levels. Also, the improvement in the swaps' maturity structure has stalled (Chart 5).

- $\quad$ Amid the recent increase in appetite for Hungary risk, non-resident holdings of government paper (MNB bills and Treasury Bonds) are now back to pre-crisis levels (Chart 6). 
Box Figure. Hungary: Crisis Vulnerabilities, Then and Now
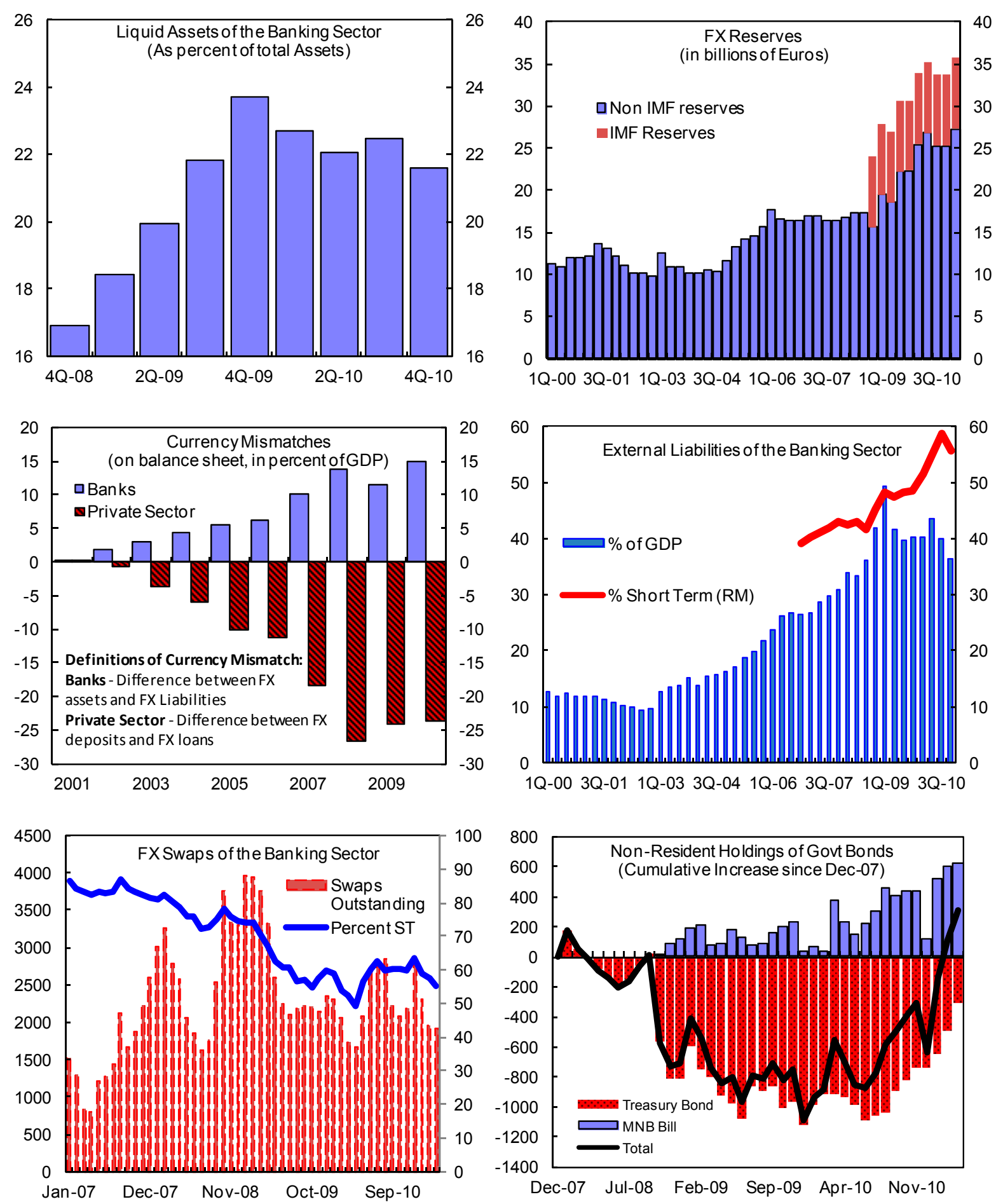

Sources: MNB; and IMF staff estimates. 


\section{B. Policy Responses}

9. The authorities have revised down their general government surplus target to 2 percent of GDP to accommodate a number of one-off expenses and weaker than initially expected revenue. (Text Table) This year's budget continues to rely heavily on oneoff asset transfers from the recently dissolved second pension pillar (10 percent of GDP), as well as transitory levies on the financial, telecommunication, energy and retail sectors. With the resulting headline fiscal balance in surplus (in ESA terms), the authorities are undertaking a number of one-time

General Governmnent Balances in 2011 (Percent of GDP, unless otherwise indicated)

\begin{tabular}{lrr}
\hline & Budget & Revised \\
\hline General govt. balance excluding one-offs & -6.0 & -5.6 \\
One-off revenue & 12.0 & 11.1 \\
o.w. pension assets & 10.8 & 10.1 \\
o.w. sector levies & 1.1 & 0.8 \\
One -off expenditure & 0.2 & 3.1 \\
o.w. MAV and BKV debt consolidation & $\ldots$ & 1.3 \\
o.w. cancellation of PPP projects & $\ldots$ & 0.7 \\
o.w. Compensation for former second pillar pension contributors & $\ldots$ & 0.9 \\
General govt. balance incl. one-offs & 5.7 & 2.3 \\
Structural balance 1/ & -3.9 & -4.5 \\
Memo items: & & \\
Net one-off items & 11.7 & 7.9 \\
Net one-off items in percent of potential GDP & 11.2 & 7.7 \\
Output gap 1/ & -4.4 & -2.3 \\
\hline Sources: Hungarian authorities; and IMF staff estimates. & &
\end{tabular}

1 / In percent of potential GDP.

expenditures, including (i) the assumption of the entire debt of public transport companies MAV and BKV, (ii) the cancellation of some previously contracted private-public partnership projects, and (iii) compensation for past voluntary contributions and real returns to the 97 percent of contributors who switched back to the first pension pillar. Moreover, after the poor budget performance in recent months, the authorities have introduced acrossthe-board expenditure cuts of 0.9 percent of GDP to help them meet the revised budget. Once accounting for the business cycle and excluding the various one-off items, staff estimates that the revised fiscal target implies a $4 \frac{1}{2}$ percent of GDP structural deficit in 2011, suggesting a further $1 / 4$ percent of GDP structural deterioration compared to 2010.

\section{The recently announced structural reform program, the Szell Kalman Plan,} aims to restore fiscal sustainability and investor confidence. The package, which relies primarily on expenditure measures, targets 1.8 percent of GDP fiscal consolidation in 2012 and an additional 1 percent of GDP in 2013 (Text Table next page). The plan spells out specific measures in some areas while providing a timetable for releasing further details later in other areas. The spending cuts focus on social benefits, eligibility for early retirement and disability pensions, health care (especially subsidized pharmaceuticals), education, and public administration (local governments, see Box 2). On the revenue side, the plan reverses previous intentions to halve the financial sector levy in 2012 and reduce the standard Corporate Income Tax (CIT) rate from 19 to 10 percent in 2013; also, a road toll system will be introduced. To bring the headline 2012 deficit below 3 percent of GDP as required under the EU's excessive deficit procedure, the authorities are also planning to make the abovementioned across-the-board expenditure cuts permanent, increase excises and fees on environmentally harmful goods, and substantially reduce the basic PIT allowance. 
Measures of the Szell Kalman Plan

(Forint billion, unless otherwise indicated)

\begin{tabular}{|c|c|c|c|}
\hline & 2011 & 2012 & 2013 \\
\hline Employment and Labor Market & 3 & 195 & 213 \\
\hline Termination of job seeking assistance & 0 & 27 & 27 \\
\hline Wage supplement system reform & 0 & 41 & 41 \\
\hline Reduction of job-seeking benefits & 0 & 43 & 43 \\
\hline Active labour market and vocational training provisions to be financed by EU funds & 0 & 41 & 41 \\
\hline Review and modification of the conditions for sick pay eligibility & 3 & 10 & 10 \\
\hline Cap on the total amount of family benefits & 0 & 15 & 15 \\
\hline Nominal freeze of family benefits & 0 & 18 & 36 \\
\hline Pension System & 12 & 93 & 129 \\
\hline Pension indexation by $\mathrm{CPI}$ & 0 & 3 & 6 \\
\hline Reduction or elimination of early retirement regimes & 0 & 0 & 3 \\
\hline Termination of special retirement rules for armed forces & 0 & 2 & 3 \\
\hline Tightening of conditions for dissability pensions' eligibility, overhaul of allowances & 12 & 88 & 117 \\
\hline Public Transport & 0 & 45 & 60 \\
\hline Consolidation of public transport companies into a single holding & 0 & 5 & 15 \\
\hline Debt takeover and cost efficiency savings in the public railways company MAV & 0 & 30 & 35 \\
\hline Reduction of the preferential tariff system & 0 & 10 & 10 \\
\hline Higher Education & 0 & 12 & 38 \\
\hline Reduction and reallocation of tuition subsidies to higher education & 0 & 5 & 16 \\
\hline Elimination of capacities not utilized, termination of statutory financing needs & 0 & 7 & 23 \\
\hline Health Care & 0 & 83 & 120 \\
\hline Increase in the payment by pharmaceutical companies & 0 & 16 & 15 \\
\hline Generic drugs program & 0 & 29 & 33 \\
\hline Revision of the therapies & 0 & 8 & 8 \\
\hline Subsidies conditional on patient cooperative behavior & 0 & 3 & 4 \\
\hline Use of international reference pricing and fixing of composite drugs & 0 & 4 & 4 \\
\hline Reduction of subsidies on drugs to reduce cholesterol & 0 & 14 & 19 \\
\hline Reform of certain treatments' financing regimes & 0 & 5 & 5 \\
\hline Overhaul of principles applied for equity consideration in individual cases & 0 & 2 & 5 \\
\hline Overhaul of the public subsidy system for the poor & 0 & 2 & 2 \\
\hline $\begin{array}{l}\text { Increase in fees in highly subsidized drugs; reduction in normative rates; review of several } \\
\text { subsidies }\end{array}$ & 0 & 0 & 25 \\
\hline State and Local Government Finances & 0 & 32 & 122 \\
\hline Re-shuffling tasks performed by local governments based on economies of scale & 0 & 15 & 100 \\
\hline $\begin{array}{l}\text { Prohibition to issue debt to finance current operations; central government approval of } \\
\text { investment loans }\end{array}$ & 0 & 0 & 0 \\
\hline Strengthening of the tax authority, simplification of taxation procedures & 0 & 5 & 10 \\
\hline Rationalization of central and background institutions; prohibition of outsourcing & 0 & 12 & 12 \\
\hline Payments by the Public Debt Reduction Fund & 0 & 90 & 220 \\
\hline Introduction of usage-based electronic toll system & 0 & 0 & 100 \\
\hline Bank Tax & 0 & 90 & 0 \\
\hline Reversal of the decision to reduce the CIT rate to 10 percent in 2013 & 0 & 0 & 120 \\
\hline Total & 12 & 549 & 901 \\
\hline In percent of GDP & 0.0 & 1.8 & 2.8 \\
\hline
\end{tabular}

Sources: Hungarian authorities; and IMF staff estimates. 


\section{Box 2. Local Government Finances}

Local government finances are under stress. Deficits are most acute in poor districts due to overreliance on income-based revenue. This regional inequality is only partially compensated by central government transfers. Fiscal deterioration is compounded during election years amid substantial political pressure for higher expenditures. As a result, local government debt has steadily risen, reaching 5 percent of GDP at end-2010.

The Szell Kalman plan seeks to address this slippage. First, the authorities hope to increase efficiency by consolidating the provision of administrative serves. And second, the plan tightens rules for local government debt issuance by preventing debt financing of current deficits and requiring central government approval for debt-financing of capital projects. However, the specifics of the plan have yet to be decided and the authorities have requested Fund technical assistance.
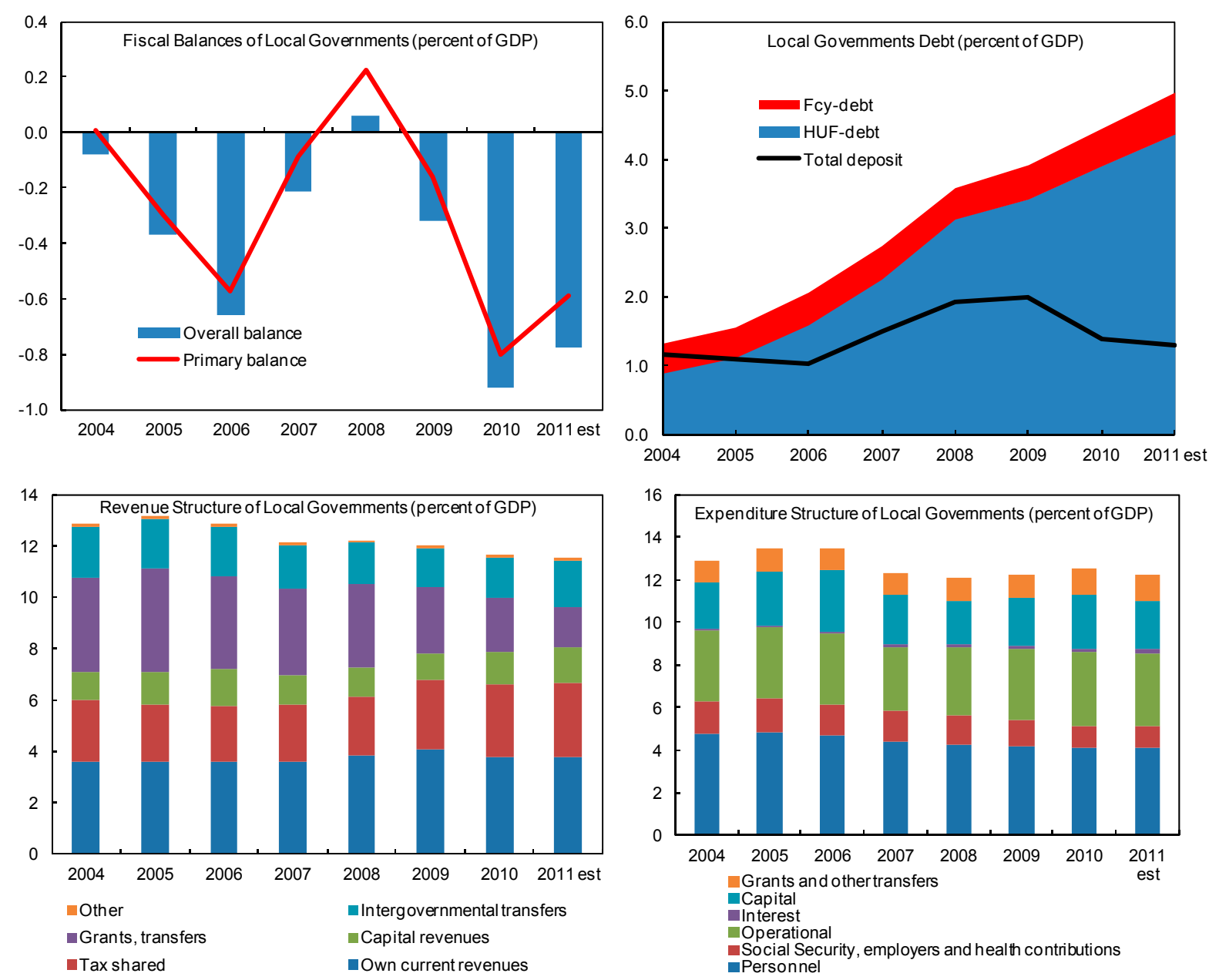

Sources: Hungarian authorities; and IMF staff estimates. 


\section{The announced consolidation efforts will occur in the context of important} changes to fiscal institutions. First, the recently approved new constitution explicitly sets a public debt ceiling of 50 percent of GDP, although the exact transitional rules for the reduction from the present 80 percent still need to be spelled out. Second, a new Fiscal Council (replacing the one dissolved in December 2010) will express an opinion each year on the soundness the government's draft budget estimates. Finally, local governments will be required to obtain Central Government approval of all debt issuance related to the financing of capital projects, and will be prohibited from issuing debt to finance current spending.

\section{On monetary policy, the MNB ended a 75-bps tightening cycle in January,} leaving the key policy rate at 6 percent. The authorities began increasing the monetary policy rate in November amid forecasted inflation above the target for the entire horizon period as well as upward pressure on the risk premium. Medium-term inflation pressures subsequently subsided as the pass-through from supply shocks turned out to be lower than forecast, allowing core inflation to remain stable. The recent decline in risk premia has also further reduced the pressure for further monetary tightening.

\section{After consultation with the banking community, the government is nearing completion on a set of measures to address strains related to mortgage portfolios.} (Box 3). The aim of the proposal is to improve the functioning of the mortgage market, contain outstanding risks associated with FX lending, and limit social hardship. To do so, the authorities plan to reverse some recent policies (moratorium on evictions and the de facto ban on FX-denominated mortgage lending), directly support the purchase of foreclosed properties (subsidies to private sector buyers and outright government purchases by a national asset management fund), and limit the impact the impact of currency volatility on bank and household balance sheets (temporary exchange rate fixing for mortgage servicing). 


\section{Box 3. Measures in the Scheme to Support Mortgage Debtors and an Efficient Functioning of the Mortgage Market}

Housing related loans stand at 25 percent of GDP, with the non-performing portion currently only 1-2 percent of GDP. If, however, there were a sharp fall in prices (e.g. when foreclosures resume) or the exchange rate $(3 / 4$ of these loans are in FX), the stress to the financial sector and the economy more broadly could be considerable. To address such potential strains, the government is developing a set of measures in consultation with the banking community. Many important details are still not known. General concerns about these proposals as conveyed to the mission are discussed in $\$ 22$.

- $\quad$ Elimination of the temporary ban on foreclosures and evictions due to mortgage default. The moratorium has been in place since 2010 to limit the social impact of the economic crisis on home owners. However, it blocks banks' access to mortgage collateral, and has therefore likely contributed to an erosion of credit discipline. It also prevents banks from effectively working out the impaired portions of their portfolios. Following the end of the moratorium, quarterly quota on the amount and geographical distribution of properties banks can foreclose will be set to limit the impact on the real estate market.

- $\quad$ Elimination of the de facto ban on euro (and possibly CHF) lending ${ }^{4}$, with a view to reduce mortgage borrowing costs. Presumably, the prudential regulations existing prior to the ban's imposition in mid-2010 would become effective again; these prescribe more conservative loan-to-value and loan-to-income ratios for euro loans relative to forint loans.

- Temporary fixing of the exchange rate for mortgage debt servicing. For mortgage debtors, the exchange rate of the Swiss franc (and possibly the euro) against the forint will be fixed at a level to be determined. Payments above the fixed amount will be accumulated in a fund for a period of 3-4 years. At the end of the fund's lifetime, its outstanding balance will be distributed over the loan's remaining maturity and will be guaranteed by the government against a fee. Depending on the interest rate used, the scheme may amount to a NPV-neutral loan rephasing, but includes fiscal risks in case the CHF remains appreciated and households default after the end of the fixing period. Calculations by the MfNE suggest that these risks are manageable.

- An interest rate subsidy for loans to purchase foreclosed property to support demand and limit the decline in real estate prices. The subsidy will only be available for loans denominated in forint, with a maximum amount of $350 \mathrm{bps}$ that will be phased out over time. To become eligible for the subsidy, the bank foreclosing the property needs to commit to paying the rent of the evicted pre-owner for a period of 18 months, and wave claims on the preowner's assets beyond the foreclosed property. Total budgeted costs amount to 0.1 percent of GDP.

- A national asset management fund, administered by local authorities but supported through the central government budget, that will purchase foreclosed properties and rent these back to the previous owner. The fund is limited to 5000 properties, with budgeted costs of less than 0.1 percent of GDP.

Elements of means-testing will likely apply to most schemes but have not yet been determined. Moreover, the schemes will be verified against state-aid provision of the EU.

\footnotetext{
${ }^{4}$ Technically, the July 2010 law bans the registration of FX-denominated mortgages in the property registry. The European Commission has been investigating if the law constitutes a violation of EU treaty obligations.
} 


\section{REPORT ON THE DISCUSSIONS}

\section{A. Macroeconomic Outlook and Risks}

\section{The combination of serious headwinds to domestic demand and ongoing positive} outlook for exports imply that the recovery will remain modest and uneven. Staff revised downward its outlook for real growth to $2 \frac{1}{2}$ percent for both this and next year, about $1 / 2$ percent less than the authorities' baseline projection. Remaining differences of view relate to the strength of German exports, the evolution of precautionary savings, the short-term contractionary effect of the Szell Kalman plan, and prospects for investment growth. Staff and the authorities agreed that, assuming full implementation of planned structural reforms, potential growth could rise to $2 \frac{1}{2}$ to 3 percent in the medium term. The authorities' medium-term projections for the external current account in the Convergence Program are, however, much more optimistic than staff's, suggesting surpluses through 2015.

\section{Staff underscored ongoing risks amid Hungary's challenging external} amortization schedule. In early 2011, Hungary benefitted from rising investor demand which both helped cover public sector financing needs and reduce inflationary pressures. However, staff highlighted that the currently benign scenario was highly exposed to both domestic policy missteps (such as delays in implementing the Szell Kalman plan) as well as exogenous events (such as a drying up of capital inflows or possible spillovers from difficulties in the European financial system). Either development could put upward pressure on risk spreads which would further depress domestic demand (via the impact of a weaker exchange rate on household balance sheets) and complicate meeting external amortizations (via lower rollover rates). The authorities agreed that these were risks but emphasized that they were mitigated by their determination to follow through with the planned fiscal adjustment.

\section{B. Policies}

\section{Structural Reform Package and Fiscal Policy}

\section{Staff welcomed the Szell Kalman Plan as a step towards restoring debt}

sustainability. Key elements of the plan - labor market and social benefit reform, deferral of permanent CIT cuts - and the publication of a timeline for legislative action are consistent with earlier Fund advice (including during the recent Article IV consultation). Taken at face value, the plan's intended savings and attending structural reforms would put public debt on a clear downward path and improve medium term growth prospects (see Text figure 2). The DSA incorporating the envisioned savings still suggests ongoing sensitivity to growth shocks (see Appendix I). Remaining differences between staff's and the authorities' projected baseline debt and deficit paths (especially in 2012) are explained by staff's more cautious macroeconomic framework and different assumptions about local government's ability to adjust spending. Some uncertainty remains about the near-term evolution of the debt stock as 
the authorities have not yet decided how much of the pension asset transfers will be used for immediate debt reduction. ${ }^{5}$
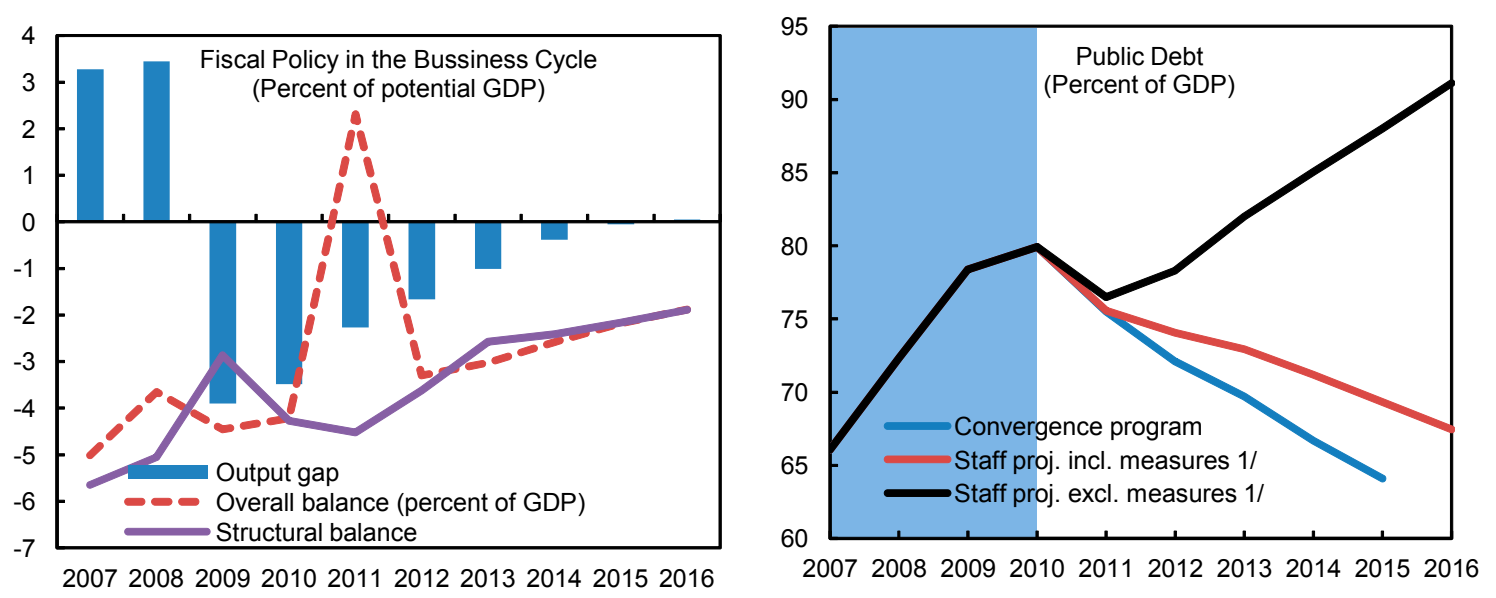

1/ The measures include the Szell Kalman Plan and the additional fiscal consolidation measures announced for 2011. Sources: Hungarian authorities; and IMF staff estimates.

\section{The authorities agreed with some, but not all, implementation risks identified by}

staff. Far-reaching social benefit cuts and revenue measures are reasonably well specified, suggesting a relatively high likelihood that they will be put in place quickly. Health and pension reforms, however, still lack detail and their outcome remains subject to the renegotiation of existing contracts (including with pharmaceutical companies) and to individual reassessments of eligibility — challenges acknowledged by the authorities. They also agreed that implementation risks loom large with respect to local government reform (see Box 2), which is why they envisaged substantial savings only from 2013 onward.

\section{Regarding prospects to address the perennial deficits of state-owned transport} companies, the authorities were more optimistic than staff. They argued that conditioning the assumption of MAV's debt on a comprehensive upfront restructuring plan, as suggested by staff, may shift this expenditure into 2012 and complicate meeting that year's deficit target agreed with the EU. While the authorities' public transport measures focus mainly on generating interest savings following the transfer of their debt to the state, staff urged to address underlying vulnerabilities such as overstaffing and other excessive operational costs.

\section{Staff also questioned the quality of some measures, including the plan's impact}

on the most vulnerable. Staff argued that means-testing of social benefits would be preferable to the planned across-the-board cuts, especially in view of the highly regressive PIT reforms passed last year. The authorities stressed that the social benefit cuts, along with a new public works program, were primarily intended to move workers at all income levels

\footnotetext{
${ }^{5}$ Government securities previously held by private pension funds (about 5 percent of GDP), will be automatically cancelled out and thus reduce debt. A yet to be determined part of the remaining 5.1 percent of GDP will be held as government assets for some time.
} 
into employment. They did express interest in fine-tuning eligibility criteria for some benefits such as child allowances, for which they requested Fund technical assistance. The authorities saw less urgency than staff in addressing overstaffing in public administration (a key area of expenditure rationalization identified by last year's TA mission) as well as state-owned enterprises.

20. Further efforts are needed to secure long-term fiscal sustainability. Specifically, pension sustainability needs to be reassessed following the de facto nationalization of the second pension pillar. In this context, staff warned the authorities against taking comfort in the improvement of the first pillar's short-term cash position and reiterated concerns about the use of some returned pension assets for current spending. The authorities pointed to the recent switch to inflation indexation, which on the margin will improve long-term sustainability. Furthermore, their Convergence Program (published after the mission) envisages continued fiscal adjustment beyond the Szell Kalman plan's measures implemented in 2012-13, aiming at a headline general government deficit of $1 \frac{1}{2}$ of GDP and public debt below 65 percent of GDP in 2015.

\section{Staff also expressed concern about several aspects of the new fiscal framework.}

While the new Fiscal Council has formal veto power over the budget and could in extremis dissolve parliament, staff thought that in practice it was unlikely to resort to such drastic actions. Moreover, the Council's mandate is more narrow than that of its predecessor: it only allows a once per year assessment of a given draft budget's feasibility rather than examining medium-term implications and educating the public on policy initiatives on an ongoing basis. Regarding the new constitutional debt limit, staff suggested to design implementation rules that allow for automatic stabilizers and avoid the pro-cyclical stance imposed by a binding debt ceiling. More generally, staff warned that the frequent changes to the fiscal framework may undermine confidence and policy stability. The authorities emphasized the latest changes were here to last, as they were anchored in the new constitution.

\section{Financial Sector Policies}

\section{Staff welcomed the government's work with banks on normalizing conditions in} the mortgage market, noting however that measures currently under consideration still lack important detail. The authorities acknowledged that the bank levy, the ban on foreignexchange lending, and the foreclosure moratorium may be weighing on credit. Furthermore, staff agreed that a proposal that combines elimination of the bans on FX lending and foreclosures with temporary relief for borrowers may help the financial sector play a stronger role in the recovery going forward. That said, staff noted that support measures need to be well-targeted to minimize moral hazard and contain fiscal risks. For example, the exchange rate used under the fixing scheme (see Box 3) should be set at distressed levels and all subsidy schemes should include elements of means-testing. Such key parameters should be clarified as soon as possible. 
23. Regarding Hungary's outsized bank levy, staff argued that its recent extension until 2013 and uncertain plans thereafter were undermining financial sector stability. Banking groups had started shifting funding and lending activity from Hungary to other countries in the region. The authorities reiterated their intention to eventually replace the levy with a smaller tax in line with emerging EU practice. Staff pointed out that an EU-wide standard was unlikely to materialize soon and suggested consideration of a financial activity tax if the purpose remained general revenue collection.

\section{The authorities noted a recent decline in the total size and average maturity of} banks' external funding. In recent months, banks have begun to reduce liquidity ratios from their elevated post-crisis levels. Though such normalization can be appropriate, the counterpart of the sale of liquid assets has largely been a repayment of long-term foreign liabilities, including to parent banks. This leaves Hungary's banks more exposed, at the margin, to shorter-term FX funding, both on balance sheet and in the FX swap market. Meanwhile, amid this shortening in the average maturity of FX funding, banks' substantial portfolio of longer term FX assets remains broadly unchanged given the average duration of mortgage loans in Swiss francs. The authorities thought that banks may be emphasizing profit at the expense of prudential considerations, which was particularly risky in light of ongoing tension in the European financial sector. Staff noted that parent banks had been a key source of additional financing during the crisis but broadly agreed with the authorities' assessment that recent developments on the whole increased liquidity risks. Furthermore, staff thought that the authorities' focus on macroprudential measures to address risks related to currency and maturity mismatch (along the lines of the Basel III stable funding ratio and liquidity coverage ratio) was appropriate, but felt that the broader issue also supported the argument for higher foreign exchange reserves going forward.

25. Staff observed that advances made in on-site inspections had been preserved, but reiterated its earlier concerns that the framework for financial stability had been weakened. On-site inspections continue at a similar frequency and intensity for systemically important banks as in the past two years. Moreover, the long-sought inspection of foreign subsidiaries of Hungarian banks in non-EU countries through an independent external auditor is now ongoing. The tri-partite financial stability council, consisting of the Hungarian Financial Supervisory Authority (HFSA), the MNB, and the Ministry of the National Economy is continuing, but its ability to initiate financial legislation or regulation on a “comply or explain" basis has been removed. Cooperation with banks' home country supervisors is also ongoing.

\section{Monetary Policy and Reserve Management}

26. Staff and the MNB agreed that putting rates on hold is adequate at this juncture. The risks from commodity prices were counterbalanced by the weak economy and improved risk premium. Looking forward, staff noted that potential monetary tightening elsewhere in Europe could complicate monetary policy if it triggered currency weakening before domestic demand had recovered. The authorities thought that such a risk was contained as they expected any tightening by the ECB to be slow in pace and moderate in degree. More 
generally, monetary policy remains constrained by the need to avoid disorderly exchange rate depreciations in view of pervasive FX exposures particularly on household balance sheets.

\section{With current reserve coverage broadly adequate but modest by some measures} (see Box 4), staff thought that going forward some additional accumulation would be useful. Higher reserves would provide a helpful safety cushion given forthcoming external financing requirements for both the banking system and the public sector. In particular, the government's challenging 2012-14 amortization schedule - including its capacity to meet obligations to the Fund ${ }^{6}$ - requires roll over rates for external market-held debt well above 100 percent. Furthermore, a reserves-to-short-term-debt ratio as low as 80 percent projected for 2011 (and only slightly increasing thereafter) compares unfavorably with neighboring countries and may have negative signaling effect in the markets. MNB staff pointed out that the short-term debt metric overstates the risks because a considerable part of such debt related to more stable parent bank funding of subsidiaries and intercompany loans. Going forward, MNB projections suggest that reserve coverage would still be within the target range suggested by its new framework for assessing reserve adequacy ${ }^{7}$, although this assumes a further pick-up up of EU transfers and sovereign debt placements.

\section{The authorities also saw drawbacks to staff's suggested means of increasing}

reserves. Several options were discussed:

- Selling all foreign assets from the pension assets transfer (rather than 60 percent, as presently planned) and depositing receipts at the MNB. The authorities pointed out that some of these assets are relatively illiquid and thus difficult to sell quickly.

- $\quad$ Small, regular and preannounced FX purchases in the foreign exchange markets (similar, for example, to Turkey). The MNB was concerned that such an announcement would be difficult to communicate in a way that did not affect the exchange rate.

- $\quad$ Issuance of long-term FX-denominated sovereign debt in excess of current financing plans. The authorities said that additional external debt accumulation, even in the short term, would run counter to their stated goal to reduce debt.

\footnotetext{
${ }^{6}$ Exposure to the IMF currently stands at $€ 8.7$ billion (9 percent of GDP and 26 percent of gross international reserves). Debt to the IMF is scheduled to be repaid mostly in 2012-13. In addition, repayments to the EU in excess of 3.5 percent of GDP are falling due in 2011 and 2014

${ }^{7}$ The MPC determines a target value for foreign-exchange reserves within a band based on three main indicators (the Guidotti-Greenspan rule, a cost-benefit optimising model and an indicator incorporating the level of gross debt), taking various auxiliary indicators into account.
} 
More generally, staff stressed that a strong policy record would help improve reserve adequacy, by increasing private sector inflows and also by facilitating Hungary's access to international back-up facilities (e.g., precautionary Fund and EU arrangements or central bank swap lines). While the authorities agreed that a sound policy mix was critical, they said that such foreign support lines were not under consideration.

\section{Box 4. Alternative Metrics of Reserve Coverage}

The literature and policy makers' experience provides a set of metrics for reserve adequacy. Traditional metrics include the extent to which the stock of reserves covers: (i) the stock of short-term debt at remaining maturity (to cover redemption obligations in the event of a drop in investors' appetite for rolling over the maturing debt); (ii) three months of imports (to cover import needs in the event of a drop in sources of foreign exchange); and (iii) 20 percent of broad money, to cover against significant capital (deposit) flight.

A new metric, recently elaborated in a Board paper (see Assessing Reserve Adequacy), looks at the level of reserves necessary to smooth the impact of large foreign exchange outflows as witnessed in severely affected crisis countries. Furthermore, the metric builds on the approach used for bank capital by "risk-weighting" different types of potential outflows. For countries with flexible exchange rate, in particular, it measures the level of reserves that would be able to cover a 30 percent reduction in short-term debt, a 10 percent reduction in other liabilities, a capital flight amounting to 5 percent of broad money, and a drop of 5 percent in exports.

Based on 2010 stocks, Hungary's reserves are at adequate levels by most metrics, but fall significantly short (75 percent or nearly $€ 11$ billion) of short-term debt at remaining maturity (see charts below). By this metric, Hungary also falls below its peers in Eastern Europe. Whether achieving a-100 percent coverage is necessary, is open for debate as it depends on the risk of a severe sudden stop in capital flows and the impact on current investors' confidence.
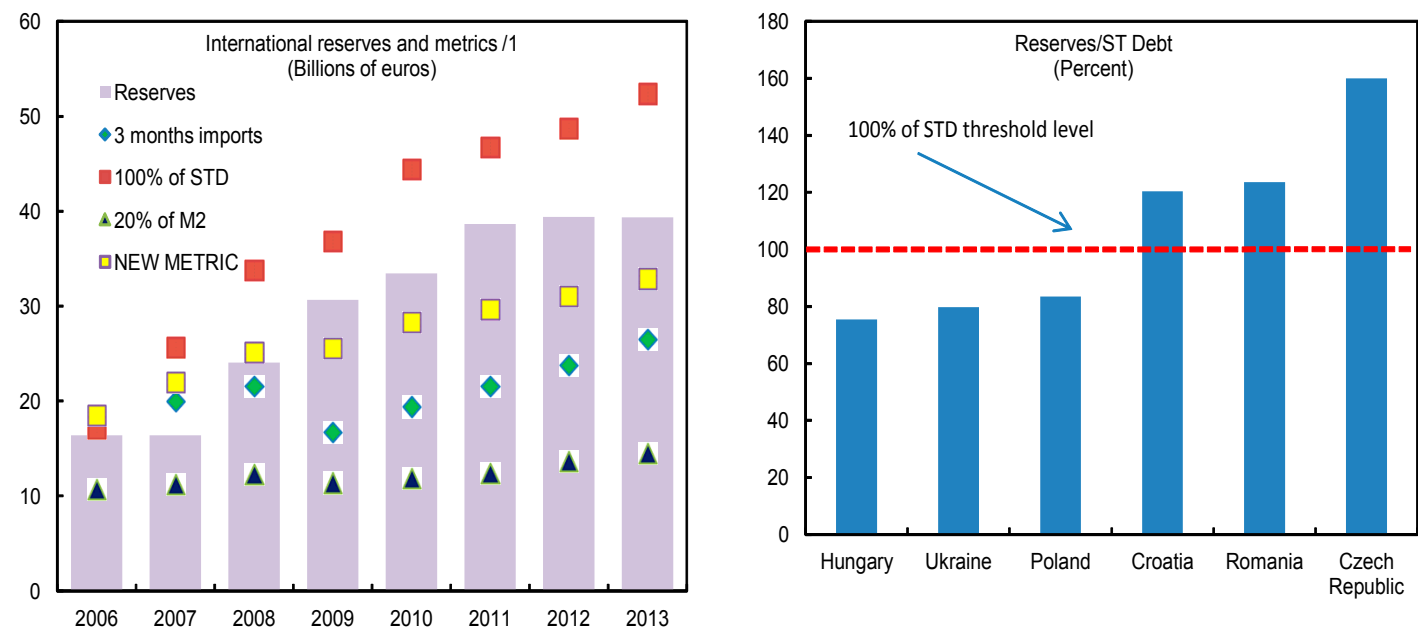

1/ The bar shows current and projected reserves in billions of Euros. The other symbols show the quantity of reserves needed to be adequate under different metrics including 3 months of imports, $100 \%$ of ST debt, and $20 \%$ of M2. The series "new metric" is a weighted combination of these

thresholds. Short-term debt includes staff's estimate of intercompany loans falling due within one year. 


\section{STAFF Appraisal}

29. Weighed down by long-standing vulnerabilities, Hungary is slowly rebounding from the 2008-09 crisis. Ongoing doubts about the policy environment as well as fundamental weakness in credit, wages, and employment have been holding back the resumption of investment and consumption. Meanwhile, exports have performed well on the back of a supportive external environment, particularly in Germany. To make the economic recovery self-sustaining, however, Hungary needs to consolidate its public finances and remove structural impediments to growth.

\section{The authorities' recently announced Szell Kalman structural reform plan} represents an effort to tackle these issues. The size and scope of the envisaged multi-year fiscal consolidation are broadly appropriate, marking a welcome departure from the ad hoc and distortionary policy steps taken in 2010. In particular, the plan rightly focuses on reducing expenditures by rationalizing public services and removing obstacles to an increase in Hungary's low labor participation rates. Taken at face value, this plan will put public debt on a downward path, reduce risk premia, and eventually lift potential growth.

\section{However, the reform plan should be modified in a number of important areas.}

More urgency should be placed on civil service reform, with concrete steps to reduce overstaffing at all levels of government. Means-testing of social benefits rather than cross-the-board cuts would be more durable and avoid placing a disproportionate burden on the most vulnerable. The restructuring of public transport companies could be more ambitious. Finally, special levies on specific sectors introduced last year should be eliminated as soon as possible, as they undermine the business climate. These steps would improve the plan's sustainability and potential to boost potential growth.

\section{Substantial implementation risks call for early and decisive action. Fiscal}

slippages in 2010 and 2011 to date highlight the difficulty of translating policy intentions into results, particularly in the context of a still weak economy. In this context, the surplus in this year's budget (which is entirely due to the one-off revenue effect of the de-facto nationalization of the second pension pillar) and the current benign market environment must not lead to complacency, especially in light of the electoral timetable and a challenging public debt amortization schedule after 2012. To reduce implementation risks, the plans' timetable for spelling out specific policies should be adhered to strictly. Some measures, such as modifications to social benefit schemes, could already be put in place in 2011, with the additional advantage of spreading out the adjustment. Finally, assuming the debt of transport companies by the state should be delayed until a credible up-front restructuring plan is developed.

33. Some recent changes to the fiscal framework could usefully be revisited. The new Fiscal Council's mandate is narrower than that of its recently abolished predecessor, limiting its ability to provide effective governance. The new constitutional debt limit provides a 
welcome signal of the authorities' determination to restore fiscal sustainability, but should be supplemented with carefully designed rules governing the transition from the present level and avoiding procyclical fiscal policies.

\section{With respect to financial sector issues, recent focus on addressing stress in real} estate portfolios is welcome, but broader risks in the sector also warrant attention. The measures now under discussion, especially the elimination of the FX lending and mortgage foreclosure ban, may help resume credit growth - although a final assessment will depend on crucial parameters that are still unknown. Support schemes for distressed mortgage holders are welcome but should be transparent and means-tested so as to minimize fiscal cost and moral hazard. Banks' large open FX position and their continued dependence on external funding call for increased vigilance, especially in view of ongoing tensions in the European financial sector. In this context, the authorities would be well advised to quickly eliminate the outsized bank levy as it is encouraging parent banks to shift funding and lending activity away from Hungary.

35. The current monetary policy stance appears appropriate. Still low core inflation and reduced risk premia allow keeping policy rates on hold for now. In light of a volatile global environment, the MNB should continue to monitor price and financial market developments closely.

\section{In view of high rollover risks for the sovereign and the banking system, some} increase in reserve coverage would provide additional insurance. Additional buffers are particularly important in view of ongoing tensions in the European financial system and large external amortizations falling due in 2012-14, including to IMF an EU. Further reserve accumulation could be achieved for example by diverting a larger share of foreign assets from the recently dissolved second pension pillar to the MNB; instituting small, regular and preannounced FX purchases; and issuing additional FX-denominated debt if market conditions remain favorable. Securing international back-up facilities, conditional on strong policy implementation, could also help. 
Table 1. Hungary: Main Economic Indicators, 2007-12

\begin{tabular}{|c|c|c|c|c|c|c|}
\hline & 2007 & 2008 & 2009 & 2010 & 2011 & 2012 \\
\hline & & & & & \multicolumn{2}{|c|}{ Projections } \\
\hline \multicolumn{7}{|l|}{ Real economy (change in percent) } \\
\hline Real GDP & 0.8 & 0.8 & -6.7 & 1.2 & 2.6 & 2.5 \\
\hline Total domestic demand $1 /$ & -1.3 & 0.8 & -10.7 & -1.1 & 1.5 & 1.1 \\
\hline Private consumption 2/ & -1.7 & 0.6 & -6.8 & -2.2 & 2.0 & 1.3 \\
\hline Public Consumption 2/ & -4.2 & 0.1 & 2.2 & -0.6 & -4.0 & 0.0 \\
\hline Gross fixed investment & 1.7 & 2.9 & -8.0 & -5.6 & 1.5 & 2.0 \\
\hline Foreign balance $1 /$ & 2.1 & 0.0 & 4.0 & 2.2 & 1.1 & 1.4 \\
\hline Exports 2/ & 16.2 & 5.7 & -9.6 & 14.1 & 9.6 & 9.3 \\
\hline Imports $2 /$ & 13.3 & 5.8 & -14.6 & 12.0 & 9.1 & 8.5 \\
\hline CPI (end year) & 7.4 & 3.5 & 5.6 & 4.7 & 3.9 & 3.0 \\
\hline CPI (average) & 8.0 & 6.1 & 4.2 & 4.9 & 4.1 & 3.4 \\
\hline Unemployment rate (average, in percent) & 7.3 & 7.9 & 10.1 & 11.2 & 11.2 & 10.9 \\
\hline Gross domestic investment (percent of GDP) 3/ & 21.4 & 21.4 & 20.9 & 19.3 & 0.0 & 19.1 \\
\hline Gross national saving (percent of GDP, from BOP) & 14.4 & 14.1 & 21.2 & 21.4 & 20.8 & 20.7 \\
\hline \multicolumn{7}{|l|}{ General government (percent of GDP), ESA-95 basis 4/ } \\
\hline Overall balance & -5.0 & -3.6 & -4.5 & -4.3 & 2.3 & -3.3 \\
\hline Primary balance & -0.9 & 0.5 & 0.1 & -0.1 & 6.2 & 0.7 \\
\hline Primary structural balance & -1.4 & -0.8 & 1.5 & -0.3 & -0.7 & 0.3 \\
\hline Debt & 66.1 & 72.3 & 78.4 & 80.2 & 75.8 & 74.3 \\
\hline \multicolumn{7}{|l|}{ Money and credit (end-of-period, percent change) } \\
\hline Broad money & 11.0 & 8.8 & 3.4 & 3.0 & 7.1 & 9.4 \\
\hline Lending to the private sector, flow-based & 18.2 & 11.7 & -2.1 & -2.4 & 0.0 & 4.0 \\
\hline \multicolumn{7}{|l|}{ Interest rates (percent) } \\
\hline T-bill (90-day, average) & 7.6 & 8.8 & 8.4 & 5.4 & $\ldots$ & $\ldots$ \\
\hline Government bond yield (5-year, average) & 7.0 & 9.3 & 9.4 & 6.7 & $\ldots$ & $\ldots$ \\
\hline \multicolumn{7}{|l|}{ Balance of payments } \\
\hline Goods and services trade balance (percent of GDP) & 0.9 & 0.4 & 5.1 & 7.2 & 7.8 & 9.0 \\
\hline Current account (percent of GDP) & -6.9 & -7.3 & 0.4 & 2.1 & 1.7 & 1.6 \\
\hline Reserves (in billions of euros) & 16.4 & 24.0 & 30.7 & 33.7 & 38.6 & 39.4 \\
\hline Gross external debt (percent of GDP) 5/ & 103.2 & 116.0 & 146.6 & 139.8 & 139.0 & 131.0 \\
\hline \multicolumn{7}{|l|}{ Exchange rate } \\
\hline Exchange regime & \multicolumn{6}{|c|}{ Floating } \\
\hline Present rate (May 6, 2011) & \multicolumn{6}{|c|}{ Ft $182.9=$ US $\$ 1 ;$ Ft. $265.4=€ 1$} \\
\hline Nominal effective rate $(2000=100$, average $)$ & 93.7 & 93.3 & 102.6 & 102.7 & $\ldots$ & $\ldots$ \\
\hline Real effective rate, CPI basis $(2000=100$, average) & 72.6 & 70.4 & 74.8 & 72.4 & $\ldots$ & $\ldots$ \\
\hline Quota at the Fund & & & SDR $103 \varepsilon$ & .4 million & & \\
\hline \multicolumn{7}{|l|}{ Memorandum Items } \\
\hline Nominal GDP (billions of forints) & 25,321 & 26,754 & 26,054 & 27,120 & 28,540 & 29,963 \\
\hline
\end{tabular}

Sources: Hungarian authorities; IMF, International Financial Statistics; Bloomberg; and IMF staff estimates.

$1 /$ Contribution to growth. Includes change in inventories.

2/ Calculated using previous year's prices

3/ Excludes change in inventories.

4/ Consists of the central government budget, social security funds, extrabudgetary funds, and local governments. It includes the impact of the government's fiscal consolidation package announced in February 2011, as estimated by the authorities, and the transfer of Pillar two pension assets to the state.

5/ Excluding Special Purpose Entities. Including inter-company loans, and nonresident holdings of forint-denominated assets. 
Table 2. Hungary: Central Bank Survey, 2006-12

(Forint billions)

\begin{tabular}{|c|c|c|c|c|c|c|c|c|c|c|}
\hline & 2006 & 2007 & 2008 & 2009 & \multicolumn{4}{|c|}{2010} & 2011 & 2012 \\
\hline & & & & & Mar & June & Sep & $\mathrm{Dec}$ & \multicolumn{2}{|c|}{ Projection } \\
\hline Net foreign assets & 3,838 & 3,941 & 5,988 & 7,261 & 7,891 & 8,764 & 8,014 & 7,449 & 8,809 & 9,005 \\
\hline Foreign Assets & 4,362 & 4,359 & 6,584 & 8,484 & 9,191 & 10,290 & 9,542 & 9,598 & 10,961 & 11,170 \\
\hline Foreign Liabilities & 524 & 418 & 596 & 1,223 & 1,300 & 1,526 & 1,528 & 2,149 & 2,151 & 2,165 \\
\hline Net domestic assets & $-1,100$ & -890 & $-2,340$ & $-4,460$ & $-5,181$ & $-5,861$ & $-5,164$ & $-4,244$ & $-5,283$ & $-5,196$ \\
\hline Net claims on government & -141 & -108 & $-1,286$ & -709 & $-1,148$ & $-1,200$ & $-1,011$ & -827 & $-1,721$ & $-1,038$ \\
\hline Assets & 233 & 147 & 360 & 279 & 279 & 260 & 260 & 249 & 262 & 262 \\
\hline Liabilities (Govt Deposits at MNB) & 373 & 255 & 1,646 & 988 & 1,427 & 1,460 & 1,271 & 1,077 & 1,983 & 1,300 \\
\hline HUF & 280 & 197 & 128 & 248 & 413 & 419 & 524 & 273 & $\ldots$ & $\cdots$ \\
\hline $\mathrm{FX}$ & 93 & 58 & 1,518 & 741 & 1,014 & 1,041 & 747 & 804 & $\ldots$ & $\ldots$ \\
\hline Net claims on banks & -998 & -706 & -913 & $-3,147$ & $-3,345$ & $-3,373$ & $-3,281$ & $-2,564$ & $-2,710$ & $-3,306$ \\
\hline Assets & 0 & 0 & 177 & 0 & 4 & 16 & 36 & 36 & 29 & 29 \\
\hline Liabilities & 998 & 706 & 1,089 & 3,147 & 3,348 & 3,389 & 3,317 & 2,601 & 2,739 & 3,336 \\
\hline Two Week Deposit Facility & 991 & 270 & -114 & 244 & -57 & 389 & -19 & 120 & 120 & 120 \\
\hline Securities Issued by MNB & 8 & 436 & 1,203 & 2,903 & 3,406 & 3,000 & 3,336 & 2,480 & 2,619 & 3,215 \\
\hline Net claims on the economy & 2 & -118 & -47 & -197 & -356 & -356 & -239 & -354 & -354 & -354 \\
\hline Other items, net & 37 & 42 & -95 & -406 & -333 & -932 & -632 & -498 & -498 & -498 \\
\hline Base money (M0) & 2,505 & 3,051 & 3,647 & 2,801 & 2,710 & 2,903 & 2,850 & 3,206 & 3,526 & 3,808 \\
\hline Currency in Circulation & 2,039 & 2,258 & 2,404 & 2,268 & 2,158 & 2,303 & 2,356 & 2,464 & 2,711 & 2,928 \\
\hline Banks' Reserves & 466 & 793 & 1,243 & 533 & 552 & 600 & 494 & 741 & 815 & 881 \\
\hline \multicolumn{11}{|l|}{ Memorandum items: } \\
\hline Base Money (yoy percent change) & 10.2 & 21.8 & 19.5 & -23.2 & -22.3 & -3.1 & -0.2 & 14.4 & 10.0 & 8.0 \\
\hline Government Deposits at Central Bank (percent of GDP) & 1.6 & 1.0 & 6.2 & 3.8 & 5.4 & 5.5 & 4.7 & 4.0 & 6.9 & 4.3 \\
\hline HUF & 1.2 & 0.8 & 0.5 & 1.0 & 1.6 & 1.6 & 2.0 & 1.0 & $\ldots$ & $\ldots$ \\
\hline FX & 0.4 & 0.2 & 5.7 & 2.8 & 3.9 & 3.9 & 2.8 & 3.0 & $\ldots$ & $\ldots$ \\
\hline Central Bank Bills Outstanding (percent of GDP) & 0.0 & 1.7 & 4.5 & 11.1 & 12.6 & 11.1 & 12.3 & 9.1 & 9.2 & 10.7 \\
\hline Portion of CB Bills Owned by Non-Residents (percent) & & 15.2 & 7.2 & 4.0 & 11.2 & 8.8 & 12.2 & $\ldots$ & $\ldots$ & $\ldots$ \\
\hline Reserve Requirement Ratio (percent of select liabilities) & 5.0 & 5.0 & 2.0 & 2.0 & 2.0 & 2.0 & 2.0 & $2 \%$ to $5 \%$ & $\ldots$ & $\ldots$ \\
\hline
\end{tabular}

Sources: Magyar Nemzeti Bank; and IMF staff estimates. 
Table 3. Hungary: Monetary Survey, 2006-11

(Forint billions)

\begin{tabular}{|c|c|c|c|c|c|c|c|c|c|c|}
\hline & 2006 & 2007 & 2008 & 2009 & \multicolumn{4}{|c|}{2010} & 2011 & 2012 \\
\hline & & & & & Mar & June & Sep & Dec & \multicolumn{2}{|c|}{ Projection } \\
\hline Net foreign assets & -78 & -947 & -1491 & 564 & 1192 & 1454 & 1216 & 1245 & 3392 & 3647 \\
\hline Central Bank & 3838 & 3941 & 5988 & 7261 & 7891 & 8764 & 8014 & 7449 & 8809 & 9005 \\
\hline Commercial Banks & -3915 & -4888 & -7478 & -6697 & -6699 & -7310 & -6798 & -6204 & -5417 & -5357 \\
\hline Net domestic assets & 12863 & 15143 & 16938 & 15410 & 14784 & 14961 & 14995 & 15201 & 14221 & 15629 \\
\hline Domestic credit & 15933 & 18302 & 21005 & 20300 & 19744 & 21107 & 20881 & 21132 & 20150 & 21540 \\
\hline Net claims on government & 3026 & 3270 & 2955 & 3035 & 2785 & 3037 & 3323 & 3458 & 2477 & 3160 \\
\hline Central Bank & -141 & -108 & -1286 & -709 & -1148 & -1200 & -1011 & -827 & -1721 & -1038 \\
\hline Commercial Banks & 3166 & 3378 & 4241 & 3744 & 3933 & 4237 & 4334 & 4286 & 4198 & 4198 \\
\hline Credit to the economy & 12908 & 15032 & 18049 & 17266 & 16959 & 18070 & 17558 & 17674 & 17674 & 18381 \\
\hline o/w Comercial Banks & 12906 & 15150 & 18099 & 17462 & 17315 & 18426 & 17798 & 18028 & 18028 & 18749 \\
\hline o/w Loans & 12857 & 15057 & 17995 & 17326 & 17174 & 18278 & 17681 & 17897 & 17897 & 18613 \\
\hline HUF & 6478 & 6449 & 6214 & 6201 & 6303 & 6184 & 6378 & 6425 & 6425 & 6682 \\
\hline $\mathrm{FX}$ & 6379 & 8608 & 11781 & 11125 & 10872 & 12094 & 11304 & 11472 & 11472 & 11931 \\
\hline o/w Securities & 46 & 87 & 97 & 118 & 123 & 132 & 101 & 116 & 116 & 121 \\
\hline Other items, net & -3071 & -3159 & -4067 & -4890 & -4961 & -6146 & -5886 & -5931 & -5929 & -5911 \\
\hline Broad money (M3) & 12785 & 14196 & 15447 & 15974 & 15976 & 16415 & 16212 & 16446 & 17614 & 19277 \\
\hline M2 & 11913 & 12937 & 14252 & 14364 & 14044 & 14328 & 14163 & 14359 & 15378 & 16830 \\
\hline M1 & 5833 & 6348 & 6162 & 6122 & 5940 & 6339 & 6317 & 6635 & 7106 & 7777 \\
\hline Currency in circulation & 1838 & 2068 & 2137 & 2039 & 1993 & 2150 & 2173 & 2218 & 2376 & 2600 \\
\hline Overnight Deposits & 3995 & 4280 & 4025 & 4082 & 3947 & 4189 & 4144 & 4417 & 4730 & 5177 \\
\hline Deposits with Maturities up to 2 years & 6080 & 6589 & 8090 & 8243 & 8104 & 7988 & 7846 & 7724 & 8272 & 9054 \\
\hline Repos & 73 & 82 & 22 & 35 & 29 & 33 & 33 & 34 & 37 & 40 \\
\hline Money Market Fund Shares/Units & 764 & 978 & 858 & 1115 & 1247 & 1345 & 1372 & 1333 & 1428 & 1563 \\
\hline Debt Securities & 35 & 200 & 316 & 460 & 656 & 709 & 643 & 720 & 771 & 844 \\
\hline \multicolumn{11}{|l|}{ Memorandum items : } \\
\hline \multicolumn{11}{|c|}{ (percentage change by contribution, y-o-y) } \\
\hline Broad Money & 13.6 & 11.0 & 8.8 & 3.4 & 0.1 & 3.4 & 2.5 & 3.0 & 7.1 & 9.4 \\
\hline NFA & -4.0 & -6.8 & -3.8 & 13.3 & 11.4 & 12.3 & 3.6 & 4.3 & 13.1 & 1.4 \\
\hline NDA & 17.7 & 17.8 & 12.6 & -9.9 & -11.3 & -8.9 & -1.1 & -1.3 & -6.0 & 8.0 \\
\hline \multicolumn{11}{|c|}{ (percentage change, y-o-y) } \\
\hline Credit to Private Sector 1/ 2/ & 20.2 & 18.2 & 11.7 & -2.1 & -2.5 & -3.4 & -2.7 & -2.4 & 0 & 4 \\
\hline HUF & 9.5 & -0.4 & -3.1 & 0.4 & 4.3 & -0.2 & 1.6 & 5.2 & $\ldots$ & $\ldots$ \\
\hline $\mathrm{FX}$ & 36.6 & 40.6 & 23.7 & -3.5 & -6.2 & -5.5 & -5.5 & -7.0 & $\ldots$ & $\ldots$ \\
\hline
\end{tabular}

Sources: Magyar Nemzeti Bank; and IMF staff estimates.

1/ Adjusted for changes in exchange rate

2/ Only credit to households and firms 
Table 4. Hungary: Balance of Payments, 2005-16 (Euro millions)

\begin{tabular}{|c|c|c|c|c|c|c|c|c|c|c|c|c|}
\hline & 2005 & 2006 & 2007 & 2008 & 2009 & 2010 & 2011 & 2012 & 2013 & 2014 & 2015 & 2016 \\
\hline & & & & & & \multicolumn{7}{|c|}{ Projection } \\
\hline Current Account & $-6,709$ & $-6,831$ & $-6,965$ & $-7,774$ & 332 & 2,031 & 1,688 & 1,680 & 317 & $-1,570$ & $-2,717$ & $-3,477$ \\
\hline Goods and service, net & $-1,408$ & $-1,228$ & 910 & 395 & 4,721 & 7,080 & 7,898 & 9,527 & 8,212 & 6,878 & 6,324 & 6,087 \\
\hline Exports & 60,022 & 69,247 & 80,946 & 86,558 & 71,697 & 84,766 & 93,835 & 103,952 & 113,836 & 124,715 & 136,800 & 150,312 \\
\hline Imports & $-61,430$ & $-70,476$ & $-80,035$ & $-86,163$ & $-66,976$ & $-77,686$ & $-85,937$ & $-94,425$ & $-105,624$ & $-117,838$ & $-130,477$ & $-144,225$ \\
\hline Income, net & $-5,019$ & $-5,298$ & $-7,372$ & $-7,583$ & $-4,747$ & $-5,441$ & $-6,455$ & $-7,944$ & $-7,999$ & $-8,583$ & $-9,187$ & $-9,710$ \\
\hline Current transfers, net & -282 & -305 & -503 & -587 & 359 & 392 & 245 & 98 & 104 & 135 & 147 & 145 \\
\hline Capital Account & 599 & 685 & 708 & 1,016 & 1,109 & 1,790 & 1,545 & 2,041 & 2,012 & 2,012 & 2,012 & 2,012 \\
\hline Net capital transfers & 586 & 670 & 789 & 919 & 1,707 & 1,790 & 1,545 & 2,041 & 2,012 & 2,012 & 2,012 & 2,012 \\
\hline Financial Account & 12,007 & 8,841 & 6,663 & 10,039 & $-3,909$ & 1,309 & 5,316 & 1,928 & 3,500 & 5,453 & 2,975 & 4,710 \\
\hline Direct investment, net & 4,417 & 2,327 & 209 & 2,809 & -443 & 580 & 429 & 551 & 1,741 & 2,084 & 2,257 & 2,358 \\
\hline Direct Investment Abroad & $-1,756$ & $-3,127$ & $-2,643$ & $-2,087$ & $-1,938$ & -628 & $-1,321$ & $-1,287$ & $-1,665$ & $-1,751$ & $-1,839$ & $-1,947$ \\
\hline In Hungary & 6,172 & 5,454 & 2,852 & 4,896 & 1,495 & 1,208 & 1,751 & 1,838 & 3,406 & 3,835 & 4,096 & 4,304 \\
\hline Portfolio investment, net $1 /$ & 3,388 & 5,222 & -789 & $-3,153$ & $-2,673$ & 615 & 7,138 & 1,276 & 1,680 & 3,275 & 558 & 2,207 \\
\hline Other investment & 4,203 & 1,292 & 7,242 & 10,383 & -793 & 114 & $-2,252$ & 101 & 79 & 94 & 161 & 145 \\
\hline Net errors and omissions & $-1,989$ & $-1,728$ & -272 & $-2,528$ & -518 & $-2,112$ & $-1,600$ & $-1,200$ & $-1,200$ & $-1,200$ & $-1,200$ & $-1,200$ \\
\hline Overall Balance & 3,908 & 968 & 134 & 753 & $-2,985$ & 3,018 & 6,949 & 4,450 & 4,630 & 4,695 & 1,071 & 2,045 \\
\hline Prospective Financing & & & & 2,000 & 3,500 & 0 & $-2,000$ & 0 & 0 & $-2,000$ & 0 & $-1,500$ \\
\hline European Union & & & & 2,000 & 3,500 & 0 & $-2,000$ & 0 & 0 & $-2,000$ & 0 & $-1,500$ \\
\hline World Bank & & & & 0 & 0 & 0 & 0 & 0 & 0 & 0 & 0 & 0 \\
\hline Bank Guarantee Fund & & & & 0 & 0 & 0 & 0 & 0 & 0 & 0 & 0 & 0 \\
\hline Net International Reserves (increase -) & $-3,908$ & -968 & -134 & $-2,753$ & -515 & $-3,018$ & $-4,949$ & $-4,450$ & $-4,630$ & $-2,695$ & $-1,071$ & -545 \\
\hline Gross Reserves & $-3,908$ & -968 & -134 & $-7,676$ & $-5,499$ & $-3,018$ & $-4,949$ & -756 & -222 & $-1,999$ & $-1,071$ & -546 \\
\hline Reserve Liabilities & 0 & 0 & 0 & 4,923 & 4,984 & 0 & 0 & $-3,694$ & $-4,407$ & -696 & 0 & 1 \\
\hline Bank Guarantee Fund & 0 & 0 & 0 & 0 & 0 & 0 & 0 & 0 & 0 & 0 & 0 & 0 \\
\hline Prospective Fund credits & 0 & 0 & 0 & 4,923 & 4,984 & 0 & 0 & $-3,694$ & $-4,407$ & -696 & 0 & 1 \\
\hline Current account (in percent of GDP) & -7.6 & -7.6 & -6.9 & -7.3 & 0.4 & 2.1 & 1.7 & 1.6 & 0.3 & -1.3 & -2.1 & -2.6 \\
\hline Gross external debt (in percent of GDP) & 81.0 & 96.5 & 103.2 & 116.0 & 146.6 & 139.8 & 139.0 & 131.0 & 122.8 & 117.7 & 113.2 & 109.4 \\
\hline $\begin{array}{l}\text { Gross official reserves } \\
\text { In percent of short-term debt }\end{array}$ & 15,721 & 16,397 & 16,385 & 24,040 & 30,676 & 33,675 & 38,624 & 39,380 & 39,602 & 41,601 & 42,672 & 43,218 \\
\hline at remaining maturity & 99.9 & 95.9 & 63.8 & 71.0 & 83.4 & 75.9 & 82.6 & 83.2 & 81.0 & 89.3 & 87.5 & 89.6 \\
\hline
\end{tabular}

Sources: Hungarian authorities; and IMF staff estimates.

$1 /$ In 2011 includes liquidation of foreign assets in 2 nd pillar pension funds projected at euro $2.5 \mathrm{bn}$. 
Table 5: Hungary. Balance of Payments, 2005-16

(Percent of GDP)

\begin{tabular}{|c|c|c|c|c|c|c|c|c|c|c|c|c|}
\hline & 2005 & 2006 & 2007 & 2008 & 2009 & 2010 & 2011 & 2012 & 2013 & 2014 & 2015 & 2016 \\
\hline & & & & & & & \multicolumn{6}{|c|}{ Projection } \\
\hline Current Account & -7.6 & -7.6 & -6.9 & -7.3 & 0.4 & 2.1 & 1.7 & 1.6 & 0.3 & -1.3 & -2.1 & -2.6 \\
\hline Goods and service, net & -1.6 & -1.4 & 0.9 & 0.4 & 5.1 & 7.2 & 7.8 & 9.0 & 7.3 & 5.8 & 5.0 & 4.5 \\
\hline Exports & 67.7 & 77.1 & 80.3 & 81.3 & 77.2 & 86.6 & 92.9 & 98.0 & 101.3 & 104.4 & 108.0 & 112.3 \\
\hline Imports & -69.3 & -78.5 & -79.4 & -80.9 & -72.1 & -79.3 & -85.0 & -89.0 & -94.0 & -98.6 & -103.0 & -107.7 \\
\hline Income, net & -5.7 & -5.9 & -7.3 & -7.1 & -5.1 & -5.6 & -6.4 & -7.5 & -7.1 & -7.2 & -7.3 & -7.3 \\
\hline Current transfers, net & -0.3 & -0.3 & -0.5 & -0.6 & 0.4 & 0.4 & 0.2 & 0.1 & 0.1 & 0.1 & 0.1 & 0.1 \\
\hline Capital Account & 0.7 & 0.8 & 0.7 & 1.0 & 1.2 & 1.8 & 1.5 & 1.9 & 1.8 & 1.7 & 1.6 & 1.5 \\
\hline Net capital transfers from the EU & 0.7 & 0.7 & 0.8 & 0.9 & 1.8 & 1.8 & 1.5 & 1.9 & 1.8 & 1.7 & 1.6 & 1.5 \\
\hline Financial Account & 13.5 & 9.8 & 6.6 & 9.4 & -4.2 & 1.3 & 5.3 & 1.8 & 3.1 & 4.6 & 2.3 & 3.5 \\
\hline Direct investment, net & 5.0 & 2.6 & 0.2 & 2.6 & -0.5 & 0.6 & 0.4 & 0.5 & 1.5 & 1.7 & 1.8 & 1.8 \\
\hline Direct Investment Abroad & -2.0 & -3.5 & -2.6 & -2.0 & -2.1 & -0.6 & -1.3 & -1.2 & -1.5 & -1.5 & -1.5 & -1.5 \\
\hline In Hungary & 7.0 & 6.1 & 2.8 & 4.6 & 1.6 & 1.2 & 1.7 & 1.7 & 3.0 & 3.2 & 3.2 & 3.2 \\
\hline Portfolio investment, net 1/ & 3.8 & 5.8 & -0.8 & -3.0 & -2.9 & 0.6 & 7.1 & 1.2 & 1.5 & 2.7 & 0.4 & 1.6 \\
\hline Other investment & 4.7 & 1.4 & 7.2 & 9.8 & -0.9 & 0.1 & -2.2 & 0.1 & 0.1 & 0.1 & 0.1 & 0.1 \\
\hline Net errors and omissions & -2.2 & -1.9 & -0.3 & -2.4 & -0.6 & -2.2 & -1.6 & -1.1 & -1.1 & -1.0 & -0.9 & -0.9 \\
\hline Overall Balance & 4.4 & 1.1 & 0.1 & 0.7 & -3.2 & 3.1 & 6.9 & 4.2 & 4.1 & 3.9 & 0.8 & 1.5 \\
\hline Prospective Financing & 0.0 & 0.0 & 0.0 & 1.9 & 3.8 & 0.0 & -2.0 & 0.0 & 0.0 & -1.7 & 0.0 & -1.1 \\
\hline European Union & 0.0 & 0.0 & 0.0 & 1.9 & 3.8 & 0.0 & -2.0 & 0.0 & 0.0 & -1.7 & 0.0 & -1.1 \\
\hline World Bank & 0.0 & 0.0 & 0.0 & 0.0 & 0.0 & 0.0 & 0.0 & 0.0 & 0.0 & 0.0 & 0.0 & 0.0 \\
\hline Bank Guarantee Fund & & & & 0 & 0 & 0 & 0 & 0 & 0 & 0 & 0 & 0 \\
\hline Net International Reserves (increase -) & -4.4 & -1.1 & -0.1 & -2.6 & -0.6 & -3.1 & -4.9 & -4.2 & -4.1 & -2.3 & -0.8 & -0.4 \\
\hline Gross Reserves & -4.4 & -1.1 & -0.1 & -7.2 & -5.9 & -3.1 & -4.9 & -0.7 & -0.2 & -1.7 & -0.8 & -0.4 \\
\hline Reserve Liabilities & 0.0 & 0.0 & 0.0 & 4.6 & 5.4 & 0.0 & 0.0 & -3.5 & -3.9 & -0.6 & 0.0 & 0.0 \\
\hline Bank Guarantee Fund & 0.0 & 0.0 & 0.0 & 0.0 & 0.0 & 0.0 & 0.0 & 0.0 & 0.0 & 0.0 & 0.0 & 0.0 \\
\hline Prospective Fund credits & 0.0 & 0.0 & 0.0 & 4.6 & 5.4 & 0.0 & 0.0 & -3.5 & -3.9 & -0.6 & 0.0 & 0.0 \\
\hline Gross external debt (in percent of GDP) & 81.0 & 96.5 & 103.2 & 116.0 & 146.6 & 139.8 & 139.0 & 131.0 & 122.8 & 117.7 & 113.2 & 109.4 \\
\hline Gross official reserves & 15,721 & 16,397 & 16,385 & 24,040 & 30,676 & 33,675 & 38,624 & 39,380 & 39,602 & 41,601 & 42,672 & 43,218 \\
\hline $\begin{array}{l}\text { In percent of short-term debt } \\
\text { at remaining maturity }\end{array}$ & 99.9 & 95.9 & 63.8 & 71.0 & 83.4 & 75.9 & 82.6 & 83.2 & 81.0 & 89.3 & 87.5 & 89.6 \\
\hline
\end{tabular}

Sources: Hungarian authorities; and staff projections.

$1 /$ In 2011 includes liquidation of foreign assets in 2 nd pillar pension funds projected at euro $2.5 \mathrm{bn}$. 
Table 6. Hungary: External Financing Needs, 2009-16

(Euros millions)

\begin{tabular}{|c|c|c|c|c|c|c|c|c|}
\hline & \multirow[t]{2}{*}{2009} & \multirow[t]{2}{*}{2010} & 2011 & 2012 & 2013 & 2014 & 2015 & 2016 \\
\hline & & & \multicolumn{6}{|c|}{ Projection } \\
\hline Total financing requirements & 30,980 & 35,704 & 37,715 & 37,199 & 40,115 & 45,944 & 43,900 & 48,094 \\
\hline Current account deficit - EU capital transfers & $-1,442$ & $-3,821$ & $-3,233$ & $-3,722$ & $-2,329$ & -442 & 705 & 1,465 \\
\hline Amortizations & 31,904 & 37,413 & 39,349 & 39,721 & 41,244 & 45,186 & 41,995 & 45,429 \\
\hline FDI (inter company) & 4,320 & 6,190 & 5,976 & 6,186 & 6,407 & 6,816 & 7,276 & 7,767 \\
\hline General government & 4,340 & 4,673 & 7,420 & 9,076 & 10,313 & 11,877 & 8,303 & 11,353 \\
\hline o/w: to IMF and EU & 0 & 0 & 2,000 & 3,694 & 4,407 & 2,696 & 0 & 1,499 \\
\hline Banks & 17,633 & 20,047 & 18,476 & 17,061 & 16,319 & 17,016 & 15,409 & 15,852 \\
\hline Other investment (mainly corporate) & 5,611 & 6,503 & 7,476 & 7,398 & 8,206 & 9,477 & 11,007 & 10,457 \\
\hline Net errors and omissions & 518 & 2,112 & 1,600 & 1,200 & 1,200 & 1,200 & 1,200 & 1,200 \\
\hline Total financing sources & 22,496 & 35,704 & 37,715 & 37,199 & 40,115 & 45,944 & 43,900 & 48,094 \\
\hline FDI net inflows (excl. inter-company) & 3,877 & 6,770 & 6,406 & 6,737 & 8,148 & 8,900 & 9,533 & 10,125 \\
\hline $\begin{array}{l}\text { Disbursements (debt) } \\
\quad \text { General government } 1 /\end{array}$ & $\begin{array}{r}25,192 \\
4,661\end{array}$ & $\begin{array}{r}31,432 \\
5,289\end{array}$ & $\begin{array}{r}32,621 \\
9,502\end{array}$ & $\begin{array}{r}30,890 \\
6,218\end{array}$ & $\begin{array}{r}31,837 \\
7,059\end{array}$ & $\begin{array}{l}38,682 \\
11,915\end{array}$ & $\begin{array}{r}35,065 \\
8,303\end{array}$ & $\begin{array}{l}38,132 \\
11,488\end{array}$ \\
\hline Banks & 13,703 & 19,022 & 15,643 & 16,959 & 16,232 & 16,915 & 15,341 & 15,774 \\
\hline Other investment (mainly corporate) & 6,828 & 7,121 & 7,476 & 7,713 & 8,546 & 9,851 & 11,421 & 10,870 \\
\hline Other portfolio flows net & $-1,074$ & 520 & 3,638 & 328 & 352 & 362 & 373 & 383 \\
\hline Drawdown in gross reserves & $-5,499$ & $-3,018$ & $-4,949$ & -756 & -222 & $-1,999$ & $-1,071$ & -546 \\
\hline Financing gap (baseline) & 8,484 & 0 & 0 & 0 & 0 & 0 & 0 & 0 \\
\hline EU loan & 3,500 & 0 & $-2,000$ & 0 & 0 & $-2,000$ & 0 & $-1,500$ \\
\hline Fund credits & 3,811 & 0 & 0 & $-3,694$ & $-4,407$ & -696 & 0 & 0 \\
\hline SDR allocation & 1,173 & 0 & 0 & 0 & 0 & 0 & 0 & 1 \\
\hline \multicolumn{9}{|l|}{ Memo items } \\
\hline Gross international reserves (level in Euro million) & 30,676 & 33,675 & 38,624 & 39,380 & 39,602 & 41,601 & 42,672 & 43,218 \\
\hline Government rollover rates & 107 & 113 & 128 & 69 & 68 & 100 & 100 & 101 \\
\hline o/w: Percent rollover on non-EU/IMF external debt & 107 & 113 & 175 & 116 & 120 & 130 & 100 & 117 \\
\hline Banks' rollover rates & 78 & 95 & 85 & 99 & 99 & 99 & 100 & 100 \\
\hline Corporate rollover rates (in percent) & 122 & 110 & 100 & 104 & 104 & 104 & 104 & 104 \\
\hline
\end{tabular}

Sources: Hungarian authorities; and IMF staff estimates.

1/ Excludes EU and IMF loans. 
Table 7. Hungary: Indicators of External Vulnerability, 2006-11

\begin{tabular}{|c|c|c|c|c|c|c|}
\hline & 2006 & 2007 & 2008 & 2009 & 2010 & $\begin{array}{r}2011 \\
\text { Est. }\end{array}$ \\
\hline \multicolumn{7}{|l|}{ Financial Indicators } \\
\hline M3, end-of-period, percent change & 13.6 & 11.0 & 8.8 & 3.4 & 3.0 & 7.1 \\
\hline Lending to the private sector, flow based, end-of-period, percentage change 1 / & 20.2 & 18.2 & 11.7 & -2.1 & -2.4 & 0.0 \\
\hline T-bill, 90-day, average, in percent & 7.0 & 7.6 & 8.8 & 8.4 & 5.4 & $\ldots$ \\
\hline Share of foreign currency liabilities in total liabilities & 39.3 & 42.4 & 45.6 & 47.0 & 45.6 & $\ldots$ \\
\hline \multicolumn{7}{|l|}{ Share of foreign currency loans by sector } \\
\hline Corporates & 47.1 & 52.6 & 60.3 & 61.3 & 60.7 & $\ldots$ \\
\hline Households & 46.8 & 59.0 & 70.7 & 70.2 & 70.6 & $\ldots$ \\
\hline Other loans & 75.4 & 81.7 & 87.1 & 85.7 & 83.2 & $\ldots$ \\
\hline Non-performing loans to gross loans $2 /$ & 2.6 & 2.3 & 3.0 & 6.7 & 9.3 & ... \\
\hline \multicolumn{7}{|l|}{ External Indicators } \\
\hline Exports of goods and services, annual percentage change & 15.4 & 16.9 & 6.9 & -17.2 & 18.2 & 10.7 \\
\hline Imports of goods and services, annual percentage change & 14.7 & 13.6 & 7.7 & -22.3 & 16.0 & 10.6 \\
\hline Real effective exchange rate, percentage change, $+=$ appreciation & -5.2 & 11.3 & 2.9 & -8.4 & 2.7 & -0.7 \\
\hline Current account balance, in percent of GDP & -7.6 & -6.9 & -7.3 & 0.4 & 2.1 & 1.7 \\
\hline Capital account, in percent of GDP & 0.8 & 0.7 & 1.0 & 1.2 & 1.8 & 1.5 \\
\hline Financial account, in percent of GDP & 9.8 & 6.6 & 9.4 & -4.2 & 1.3 & 5.3 \\
\hline Net foreign direct investment, in percent of GDP & 2.6 & 0.2 & 2.6 & -0.5 & 0.6 & 0.4 \\
\hline Gross official reserves, in millions of euros & 16,397 & 16,385 & 24,040 & 30,676 & 33,675 & 38,624 \\
\hline In months of imports of goods and services & 2.5 & 2.3 & 4.3 & 4.7 & 4.7 & 4.9 \\
\hline In percent of short-term debt at remaining maturity & 95.9 & 63.8 & 71.0 & 83.4 & 75.9 & 82.6 \\
\hline Total external debt, including SPEs, in percent of GDP 3/ & 111.9 & 119.7 & 148.6 & 177.3 & $\ldots$ & $\ldots$ \\
\hline Total external debt, excluding SPEs, in percent of GDP & 96.5 & 103.2 & 116.0 & 146.6 & 139.8 & 139.0 \\
\hline \multicolumn{7}{|l|}{ Of which: } \\
\hline Direct investment intercompany loans & 14.7 & 16.4 & 22.8 & 30.7 & 30.7 & 30.7 \\
\hline General government & 33.2 & 33.7 & 36.0 & 42.4 & 42.4 & 42.4 \\
\hline Of which: non-residents holdings of local currency government bonds & 13.0 & 12.8 & 8.0 & 8.7 & 8.7 & 8.7 \\
\hline Central bank & 1.1 & 0.6 & 1.1 & 5.1 & 5.1 & 5.1 \\
\hline Short-term debt at remaining maturity 4 / & 17,100 & 25,663 & 33,845 & 36,801 & 44,384 & 46,766 \\
\hline \multicolumn{7}{|l|}{ Financial Market Indicators } \\
\hline Stock market index, local currency, end-of-period & 24,844 & 26,236 & 12,242 & 21,227 & 21,460 & $\ldots$ \\
\hline EMBI Global bonds spread, end-of-period & 58.0 & 84.0 & 504.0 & 186.0 & 411.0 & $\ldots$ \\
\hline CDS spread, 5-year, end-of-period & 20.8 & 54.8 & 419.1 & 237.9 & 383.9 & $\ldots$ \\
\hline
\end{tabular}

Source: Hungarian authorities; and IMF staff estimates.

$1 /$ Loans to households and non-financial corporations adjusted for movements in the exchange rate.

2/ Non-performing loans are defined as corporate, household, interbank, foreign and other loans that are past due for more than 90 days.

3/ Special Purpose Entities are defined as resident corporations of non-resident owners, which perform a passive, financial intermediary function between th non-resident partners. SPEs have a marginal impact on the domestic economy, and their transactions have negligible net impact on the balance of payment: (an enterprise that has a non-negligible net impact on the balance of payments is removed from the list of SPEs). Foreign assets and liabilities of SPEs are largely matched, and loans are considered as FDI in accordance with international statistical standards. Data for SPEs are not available prior to 2006. 4 / Includes an estimate of intercompany loans falling due in the short-term. 
Table 8. Hungary: Staff's Illustrative Medium-Term Scenario, 2007-16

\begin{tabular}{|c|c|c|c|c|c|c|c|c|c|c|c|c|}
\hline & 2007 & 2008 & 2009 & 2010 & 2011 & 2012 & 2013 & 2014 & 2015 & 2016 & $\begin{array}{l}\text { Average } \\
2002-07\end{array}$ & $\begin{array}{l}\text { Average } \\
2013-16\end{array}$ \\
\hline & \multicolumn{12}{|c|}{ Projections } \\
\hline \multicolumn{13}{|c|}{ (In percent, unless otherwise indicated) } \\
\hline Real GDP growth & 0.8 & 0.8 & -6.7 & 1.2 & 2.6 & 2.5 & 3.0 & 3.2 & 3.1 & 2.8 & 3.4 & 3.0 \\
\hline Nominal GDP, forint billions & 25,321 & 26,754 & 26,054 & 27,120 & 28,540 & 29,963 & 31,741 & 33,742 & 35,780 & 37,814 & & \\
\hline Inflation (CPI; year average basis) & 8.0 & 6.1 & 4.2 & 4.9 & 4.1 & 3.4 & 3.0 & 3.0 & 3.0 & 3.0 & 5.4 & 3.0 \\
\hline Inflation (CPI; end-year basis) & 7.4 & 3.5 & 5.6 & 4.7 & 3.9 & 3.0 & 3.0 & 3.0 & 3.0 & 3.0 & & \\
\hline \multicolumn{13}{|c|}{ (Annual percentage change, constant prices) } \\
\hline Domestic demand & -1.3 & 0.8 & -10.8 & -1.1 & 1.6 & 1.2 & 5.0 & 5.0 & 4.2 & 3.5 & 2.9 & 4.4 \\
\hline Total consumption & -2.0 & 0.5 & -5.7 & -2.0 & 1.2 & 1.1 & 4.9 & 4.7 & 4.2 & 3.3 & 3.8 & 4.3 \\
\hline Gross fixed capital formation & 1.7 & 2.9 & -8.0 & -5.6 & 1.5 & 2.0 & 5.0 & 6.0 & 4.0 & 4.3 & 4.1 & 4.8 \\
\hline Exports of GNFS & 16.2 & 5.7 & -9.6 & 14.1 & 9.6 & 9.3 & 8.2 & 8.1 & 8.1 & 8.0 & 11.9 & 8.1 \\
\hline Imports of GNFS & 13.3 & 5.8 & -14.6 & 12.0 & 9.1 & 8.5 & 10.8 & 10.2 & 9.4 & 8.8 & 10.9 & 9.8 \\
\hline Lending to the private sector, flow-based (current prices, e.o.p.) & 18.2 & 11.7 & -2.1 & -2.4 & 0.0 & 4.0 & $\ldots$ & $\ldots$ & $\ldots$ & $\ldots$ & $\ldots$ & .. \\
\hline Unemployment rate (percent of labor force, year average basis) & 7.3 & 7.9 & 10.1 & 11.2 & 11.2 & 10.9 & 10.7 & 10.1 & 9.5 & 8.9 & 6.6 & 9.8 \\
\hline \multicolumn{13}{|c|}{ (In percent of GDP, unless otherwise indicated) } \\
\hline External current account balance & -6.9 & -7.3 & 0.4 & 2.1 & 1.7 & 1.6 & 0.3 & -1.3 & -2.1 & -2.6 & -7.6 & -1.4 \\
\hline Gross national saving & 14.4 & 14.1 & 21.2 & 21.4 & 20.8 & 20.7 & 19.8 & 18.7 & 18.1 & 18.0 & 14.8 & 18.6 \\
\hline Gross national investment 1 / & 21.4 & 21.4 & 20.9 & 19.3 & 19.1 & 19.1 & 19.5 & 20.0 & 20.2 & 20.5 & 22.3 & 20.1 \\
\hline Capital account, net & 0.7 & 1.0 & 1.2 & 1.8 & 1.5 & 1.9 & 1.8 & 1.7 & 1.6 & 1.5 & & \\
\hline Financial account, net & 6.6 & 9.4 & -4.2 & 1.3 & 5.3 & 1.8 & 3.1 & 4.6 & 2.3 & 3.5 & $\ldots$ & ... \\
\hline Gross external debt $2 /$ & 103.2 & 116.0 & 146.6 & 139.8 & 139.0 & 131.0 & 122.8 & 117.7 & 113.2 & 109.4 & $\ldots$ & ... \\
\hline \multicolumn{13}{|l|}{ General government (ESA-95) } \\
\hline Revenue, total & 45.0 & 45.2 & 46.1 & 44.6 & 52.5 & 42.4 & 41.6 & 41.8 & 42.0 & 42.2 & 42.5 & 41.9 \\
\hline Expenditure, primary & 45.9 & 44.7 & 46.0 & 44.7 & 46.2 & 41.7 & 40.6 & 40.4 & 40.2 & 40.2 & 46.2 & 40.4 \\
\hline Primary balance $3 /$ & -0.9 & 0.5 & 0.1 & -0.1 & 6.2 & 0.7 & 0.9 & 1.4 & 1.8 & 2.0 & -3.5 & 1.5 \\
\hline General government balance (including the costs of pension reform) & -5.0 & -3.6 & -4.5 & -4.3 & 2.3 & -3.3 & -3.0 & -2.6 & -2.2 & -1.9 & -7.4 & -2.4 \\
\hline Interest expenditure & 4.1 & 4.1 & 4.5 & 4.1 & 3.9 & 4.0 & 4.0 & 4.0 & 3.9 & 3.9 & 3.8 & 3.9 \\
\hline General government debt & 66.1 & 72.3 & 78.4 & 80.2 & 75.8 & 74.3 & 73.2 & 71.4 & 69.5 & 67.7 & 61.1 & 70.5 \\
\hline \multicolumn{13}{|l|}{ Memorandum items } \\
\hline Output gap & 3.3 & 3.4 & -3.9 & -3.5 & -2.3 & -1.7 & -1.0 & -0.4 & 0.0 & 0.0 & & \\
\hline Potential GDP growth & 1.2 & 0.7 & 0.4 & 0.8 & 1.3 & 1.8 & 2.3 & 2.6 & 2.7 & 2.8 & 2.6 & 2.4 \\
\hline Structural general government balance & -5.6 & -5.1 & -2.9 & -4.3 & -4.5 & -3.6 & -2.6 & -2.4 & -2.2 & -1.9 & $\ldots$ & ... \\
\hline Structural primary balance (in percent of potential GDP) & -1.4 & -0.8 & 1.5 & -0.3 & -0.7 & 0.3 & 1.4 & 1.6 & 1.8 & 2.0 & $\ldots$ & .. \\
\hline Gross official reserves (percent of short-term debt at remaining maturity) & 63.8 & 71.0 & 83.4 & 75.9 & 82.6 & 83.2 & 81.0 & 89.3 & 87.5 & 89.6 & $\ldots$ & \\
\hline
\end{tabular}

Sources: Hungarian authorities; and staff estimates.

1/ Excludes change in inventories.

2/ Excluding Special Purpose Entities. Including inter-company loans, and nonresident holdings of forint-denominated assets.

$3 /$ Includes interest revenue. 
Table 9. Hungary: Consolidated General Government, 2008-16 1/ (In percent of GDP, unless otherwise indicated)

\begin{tabular}{|c|c|c|c|c|c|c|c|c|c|}
\hline & 2008 & 2009 & 2010 & 2011 & 2012 & 2013 & 2014 & 2015 & 2016 \\
\hline & & & & \multicolumn{6}{|c|}{ Projections } \\
\hline Total revenues & 45.2 & 46.0 & 44.4 & 42.3 & 42.4 & 41.6 & 41.8 & 42.0 & 42.2 \\
\hline Current revenues and current transfers (incl. grants) & 44.6 & 44.6 & 42.5 & 40.3 & 40.3 & 39.5 & 39.7 & 39.9 & 40.2 \\
\hline Tax revenues & 39.8 & 39.3 & 37.1 & 35.9 & 36.0 & 34.8 & 35.0 & 35.2 & 35.5 \\
\hline Taxes on income, profits and capital gains & 10.5 & 9.8 & 8.4 & 7.1 & 6.9 & 5.6 & 5.6 & 5.6 & 5.7 \\
\hline Personal income tax & 7.6 & 7.3 & 6.4 & 4.6 & 4.5 & 4.0 & 4.0 & 4.0 & 4.1 \\
\hline Corporate income tax & 2.6 & 2.2 & 0.1 & 0.5 & 0.5 & 0.5 & 0.5 & 0.5 & 0.5 \\
\hline Levy on financial institutions & 0.0 & 0.0 & 0.6 & 0.6 & 0.6 & 0.3 & 0.3 & 0.3 & 0.3 \\
\hline Levy on energy, telecommunication, and retail companies & 0.0 & 0.0 & 0.4 & 0.5 & 0.5 & 0.0 & 0.0 & 0.0 & 0.0 \\
\hline Other (incl. wealth, capital, and property taxes) & 0.3 & 0.3 & 0.8 & 0.8 & 0.8 & 0.8 & 0.8 & 0.8 & 0.8 \\
\hline Taxes on payroll and workforce and Social Security contributions & 13.7 & 13.1 & 12.0 & 12.5 & 12.4 & 12.7 & 12.7 & 12.8 & 13.0 \\
\hline Taxes on goods and services & 15.5 & 16.3 & 16.7 & 16.3 & 16.6 & 16.6 & 16.7 & 16.8 & 16.8 \\
\hline VAT & 7.6 & 8.3 & 8.5 & 8.2 & 8.3 & 8.3 & 8.4 & 8.5 & 8.5 \\
\hline Other (incl. excises and duties) & 7.9 & 8.1 & 8.2 & 8.1 & 8.3 & 8.3 & 8.3 & 8.3 & 8.3 \\
\hline Current non-tax revenues & 4.0 & 4.3 & 4.2 & 3.3 & 3.3 & 3.7 & 3.7 & 3.7 & 3.7 \\
\hline Current transfers (incl. grants) & 0.8 & 1.0 & 1.3 & 1.0 & 1.0 & 1.0 & 1.0 & 1.0 & 1.0 \\
\hline Capital revenues and capital transfers (incl. grants) & 0.6 & 1.4 & 1.9 & 2.1 & 2.1 & 2.1 & 2.1 & 2.1 & 2.1 \\
\hline Total expenditures $3 /$ & 48.8 & 50.5 & 48.9 & 50.1 & 45.7 & 44.6 & 44.4 & 44.2 & 44.1 \\
\hline Current expenditures and current transfers & 44.7 & 46.3 & 44.3 & 42.5 & 40.9 & 39.9 & 39.7 & 39.5 & 39.4 \\
\hline Compensation of employees $2 /$ & 11.5 & 11.4 & 10.7 & 10.2 & 10.0 & 9.6 & 9.6 & 9.6 & 9.5 \\
\hline Goods and services & 7.1 & 7.7 & 7.7 & 7.1 & 7.0 & 6.9 & 6.8 & 6.8 & 6.8 \\
\hline Interest payments & 4.1 & 4.5 & 4.1 & 3.9 & 4.0 & 4.0 & 4.0 & 3.9 & 3.9 \\
\hline Subsidies & 1.1 & 0.9 & 0.9 & 0.9 & 0.5 & 0.4 & 0.4 & 0.3 & 0.3 \\
\hline Current transfers to households & 18.5 & 19.1 & 18.3 & 17.8 & 17.0 & 16.5 & 16.4 & 16.4 & 16.4 \\
\hline Social security & 14.2 & 14.6 & 14.2 & 14.3 & 13.5 & 13.0 & 13.0 & 12.9 & 12.9 \\
\hline Of which unemployment benefits & 0.4 & 0.6 & 0.6 & 0.5 & 0.5 & 0.5 & 0.5 & 0.5 & 0.5 \\
\hline Other & 4.3 & 4.5 & 4.1 & 3.5 & 3.5 & 3.5 & 3.5 & 3.5 & 3.4 \\
\hline Other current transfers & 2.3 & 2.6 & 2.4 & 2.5 & 2.5 & 2.5 & 2.5 & 2.5 & 2.5 \\
\hline Capital expenditures $3 /$ & 2.7 & 3.1 & 3.3 & 3.9 & 3.2 & 3.2 & 3.2 & 3.2 & 3.1 \\
\hline Capital transfers 4/ & 1.4 & 1.2 & 1.3 & 3.8 & 1.5 & 1.5 & 1.5 & 1.5 & 1.5 \\
\hline General government balance (excl. transfer of pension assets) & -3.6 & -4.6 & -4.5 & -7.8 & -3.3 & -3.0 & -2.6 & -2.2 & -1.9 \\
\hline Transfer of assets from the 2 nd to the 1 st pillar of the pension system $5 /$ & 0.0 & 0.1 & 0.2 & 10.1 & 0.0 & 0.0 & 0.0 & 0.0 & 0.0 \\
\hline General government balance & -3.6 & -4.5 & -4.3 & 2.3 & -3.3 & -3.0 & -2.6 & -2.2 & -1.9 \\
\hline Primary balance & 0.5 & 0.1 & -0.1 & 6.2 & 0.7 & 0.9 & 1.4 & 1.8 & 2.0 \\
\hline Convergence program overall balance & .. & .. & -4.2 & 2.0 & -2.5 & -2.2 & -1.9 & -1.5 & \\
\hline Gap to convergence program & .. & .. & 0.1 & -0.3 & 0.8 & 0.8 & 0.7 & 0.7 & \\
\hline \multicolumn{10}{|l|}{ Memorandum items: } \\
\hline Revenues including pension asset transfer & 45.2 & 46.1 & 44.6 & 52.5 & 42.4 & 41.6 & 41.8 & 42.0 & 42.2 \\
\hline Primary expenditure 5/ & 44.7 & 46.0 & 44.7 & 46.2 & 41.7 & 40.6 & 40.4 & 40.2 & 40.2 \\
\hline Output gap (in percent of potential GDP) & 3.4 & -3.9 & -3.5 & -2.3 & -1.7 & -1.0 & -0.4 & 0.0 & 0.0 \\
\hline Cyclically-adjusted overall balance (CAB, in percent of potential GDP) & -5.3 & -2.6 & -3.1 & 3.2 & -2.5 & -2.6 & -2.4 & -2.2 & -1.9 \\
\hline Change in $C A B$ & 1.3 & 2.7 & -0.5 & 6.3 & -5.7 & 0.0 & 0.2 & 0.2 & 0.3 \\
\hline One-off items (net) & -0.3 & 0.3 & 1.2 & 7.7 & 1.1 & 0.0 & 0.0 & 0.0 & 0.0 \\
\hline Structural balance (in percent of potential GDP) & -5.1 & -2.9 & -4.3 & -4.5 & -3.6 & -2.6 & -2.4 & -2.2 & -1.9 \\
\hline Change in the structural balance & 0.6 & 2.2 & -1.4 & -0.2 & 0.9 & 1.0 & 0.2 & 0.2 & 0.3 \\
\hline Primary structural balance (in percent of potential GDP) & -0.8 & 1.5 & -0.3 & -0.7 & 0.3 & 1.4 & 1.6 & 1.8 & 2.0 \\
\hline Change in the primary structural balance 5 / & 0.6 & 2.3 & -1.8 & -0.4 & 1.0 & 1.1 & 0.2 & 0.2 & 0.2 \\
\hline Targeted impact of February 2011 structural fiscal program 6/ & .. &.. &.. &.. & 1.8 & 2.8 & 2.8 & 2.7 & 2.5 \\
\hline Revenues & .. &.. & .. & .. & 0.3 & 0.7 & 0.7 & 0.6 & 0.6 \\
\hline Expenditure & .. & .. &.. &.. & 1.5 & 2.1 & 2.1 & 2.0 & 1.9 \\
\hline Gross public debt & 72.3 & 78.4 & 80.2 & 75.8 & 74.3 & 73.2 & 71.4 & 69.5 & 67.7 \\
\hline GDP, in current prices (forint billions, yearly) & 26,754 & 26,054 & 27,120 & 28,540 & 29,963 & 31,741 & 33,742 & 35,780 & 37,814 \\
\hline Real GDP growth (in percent) & 0.8 & -6.7 & 1.2 & 2.6 & 2.5 & 3.0 & 3.2 & 3.1 & 2.8 \\
\hline \multicolumn{10}{|l|}{ In nominal terms (HUF billions) } \\
\hline Total revenue & 12,086 & 11,980 & 12,031 & 12,085 & 12,704 & 13,198 & 14,095 & 15,029 & 15,963 \\
\hline Of which tax revenues & 10,640 & 10,233 & 10,053 & 10,247 & 10,775 & 11,054 & 11,816 & 12,612 & 13,408 \\
\hline Total expenditure & 13,062 & 13,168 & 13,248 & 14,311 & 13,691 & 14,159 & 14,967 & 15,808 & 16,674 \\
\hline Of which primary expenditure & 11,964 & 11,985 & 12,129 & 13,194 & 12,504 & 12,898 & 13,624 & 14,395 & 15,207 \\
\hline Transfer of assets & 0 & 26 & 64 & 2,885 & 0 & 0 & 0 & 0 & 0 \\
\hline Primary balance & 122 & 20 & -34 & 1,776 & 201 & 301 & 472 & 634 & 756 \\
\hline Overall balance & -976 & $-1,162$ & $-1,153$ & 659 & -987 & -961 & -871 & -779 & -711 \\
\hline
\end{tabular}

Sources: Hungarian authorities; and IMF staff estimates.

1/ Data are classified following the ESA'95 methodology, as reported to the European Commission.

$2 /$ Including social security contributions.

3/ In 2011 includes HUF $200 \mathrm{bn}$. of one-off expenditures allocated to the cancellation of PPP projects.

4/ In 2011 includes one-off expenditures estimated at HUF $300 \mathrm{bn}$. for the consolidation of MAV debt, and also one-off HUF 78 bn. for the consolidation of BKV debt.

5/ For 2012-2014, all non-interest expenditure categories are projected using the potential GDP projected growth rate.

6/ The projected revenue and expenditure impacts are as reported by the authorities for 2012 and 2013 . Starting in 2014 the impact of the revenue measures is calculated

according to the projected evolution of the corresponding tax bases, and the evolution of expenditures according to the growth of potential GDP. 
Table 10. Hungary: Central Government Financing, 2010-16

(Percent of GDP)

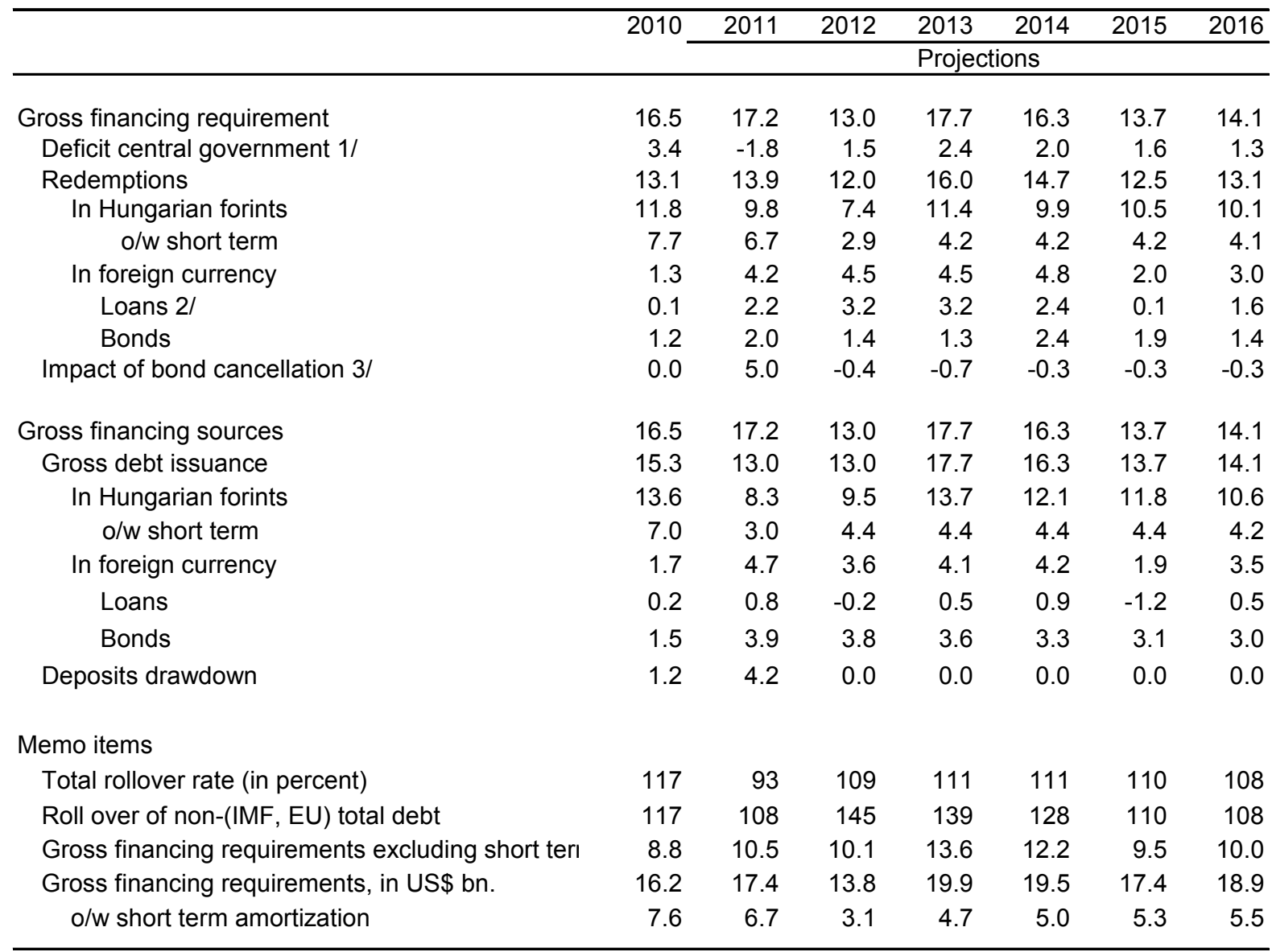

Sources: AKK data; and IMF staff estimates.

1/ In 2011 includes projected revenues of HUF 2885 bn. of assets that were part of the private pension asset stock, of which HUF 1448 bn. are government bonds with an automatic debt cancellation impact. It is assumed that about 3/4 of the remaining non-government bond assets are liquidated in 2011 and used for financing purposes.

2/ Includes primarily central government repayments to the IMF and EU.

3/ Assumes all debt cancellation applies to debt denominated in domestic currency only. The negative flows represent reduction in amortization on cancelled bonds, assumed to have the same maturity profile as total debt in domestic currency. 
Table 11. Hungary: Financial Soundness Indicators for the Banking Sector, 2008-10

(Percent, unless otherwise indicated, end of period)

\begin{tabular}{|c|c|c|c|c|c|c|}
\hline & 2008 & 2009 & $2010 Q 1$ & 2010Q2 & 2010Q3 & 2010Q4 \\
\hline \multicolumn{7}{|l|}{ Capital adequacy } \\
\hline Regulatory capital to risk-weighted assets & 12.4 & 13.9 & 14.2 & 13.5 & 13.9 & 14.1 \\
\hline Tier 1 Capital to risk-weighted assets & 10.2 & 11.6 & 11.8 & 11.1 & 11.5 & 11.6 \\
\hline \multicolumn{7}{|l|}{ Asset composition and quality } \\
\hline NPLs net of provisions to capital & 12.7 & 20.4 & 18.2 & 24.6 & 27.9 & 30.6 \\
\hline NPLs to gross loans & 2.9 & 6.3 & 7.2 & 7.9 & 9.1 & 9.1 \\
\hline Loan Growth & 20.9 & -8.5 & -16.0 & 0.8 & -1.8 & -0.7 \\
\hline \multicolumn{7}{|l|}{ Distribution of Bank Loans by Borrower } \\
\hline Households & 36.7 & 37.7 & 38.3 & 39.2 & 39.5 & 40.4 \\
\hline Firms & 36.0 & 35.9 & 35.6 & 34.2 & 34.9 & 34.6 \\
\hline Other Financial Institutions & 10.0 & 8.6 & 8.3 & 8.2 & 8.0 & 8.0 \\
\hline Non-Residents & 11.6 & 11.8 & 11.5 & 11.9 & 11.0 & 10.3 \\
\hline Other & 5.7 & 6.1 & 6.3 & 6.4 & 6.6 & 6.8 \\
\hline \multicolumn{7}{|l|}{ Denomination of FX Loans to Corporates } \\
\hline EUR & 66.9 & 75.2 & 74.6 & 75.0 & 76.0 & 75.9 \\
\hline USD & 4.1 & 3.4 & 3.6 & 3.4 & 3.4 & 3.0 \\
\hline $\mathrm{CHF}$ & 27.8 & 20.6 & 21.0 & 20.7 & 20.4 & 20.8 \\
\hline Other & 1.1 & 0.9 & 0.8 & 0.9 & 0.3 & 0.3 \\
\hline \multicolumn{7}{|l|}{ Earnings and profitability } \\
\hline Average ROA (before tax) & 1.2 & 0.6 & 1.2 & 0.8 & 0.4 & 0.1 \\
\hline Average ROE (before tax) & 16.6 & 8.3 & 14.1 & 9.9 & 4.9 & 1.3 \\
\hline Net interest income to gross income & 65.4 & 66.8 & 71.7 & 70.8 & 72.0 & 71.9 \\
\hline Noninterest expenses to gross income & 59.3 & 48.9 & 47.0 & 45.6 & 46.4 & 48.4 \\
\hline Personnel Expenses to Non-Interest Expenses & 49.4 & 48.2 & 48.1 & 48.0 & 47.7 & 49.6 \\
\hline \multicolumn{7}{|l|}{ Liquidity } \\
\hline Liquid assets to total assets & 16.9 & 23.7 & 22.7 & 22.0 & 22.5 & 21.6 \\
\hline Liquid assets to short term liabilities & 33.0 & 45.7 & 43.6 & 43.2 & 43.3 & 41.4 \\
\hline Loans to deposits & 125.1 & 115.1 & 111.6 & 115.7 & 112.9 & 115.4 \\
\hline \multicolumn{7}{|l|}{ Sensitivity to market risk } \\
\hline Net open position in FX to capital & 15.3 & 17.8 & 13.8 & 13.8 & 15.6 & 15.5 \\
\hline
\end{tabular}

Source: Magyar Nemzeti Bank. 
Table 12. Hungary: Indicators of Fund Credit, 2008-16 (SDR millions)

\begin{tabular}{|c|c|c|c|c|c|c|c|c|c|}
\hline & 2008 & 2009 & 2010 & 2011 & 2012 & 2013 & 2014 & 2015 & 2016 \\
\hline \multicolumn{10}{|l|}{ Existing and prospective Fund credit } \\
\hline Disbursement & 4,215 & 3,422 & 0 & 0 & 0 & 0 & 0 & 0 & 0 \\
\hline Stock $1 /$ & 4,215 & 7,637 & 7,637 & 7,637 & 4,417 & 598 & 0 & (0) & (0) \\
\hline Obligations & 0 & 148 & 186 & 186 & 3,384 & 3,878 & 603 & 0 & 0 \\
\hline Repurchase & 0 & 0 & 0 & 0 & 3,220 & 3,819 & 598 & 0 & 0 \\
\hline Charges & 0 & 148 & 186 & 186 & 164 & 59 & 5 & 0 & 0 \\
\hline \multicolumn{10}{|l|}{ Stock of existing and prospective Fund credit } \\
\hline In percent of quota & 405.9 & 735.5 & 735.5 & 735.5 & 425.3 & 57.6 & 0.0 & $(0.0)$ & $(0.0)$ \\
\hline In percent of GDP & 4.3 & 9.1 & 9.0 & 8.6 & 4.8 & 0.6 & 0.0 & $(0.0)$ & $(0.0)$ \\
\hline In percent of exports of goods and services & 5.2 & 11.8 & 10.4 & 9.3 & 4.9 & 0.6 & 0.0 & $(0.0)$ & $(0.0)$ \\
\hline In percent of gross reserves & 18.8 & 27.6 & 26.2 & 22.7 & 12.9 & 1.8 & 0.0 & $(0.0)$ & $(0.0)$ \\
\hline \multicolumn{10}{|c|}{ Obligations to the Fund from existing and prospective Fund arrangements } \\
\hline In percent of quota & 0.0 & 14.2 & 17.9 & 17.9 & 325.9 & 373.4 & 58.1 & 0.0 & 0.0 \\
\hline In percent of GDP & 0.0 & 0.2 & 0.2 & 0.2 & 3.7 & 4.0 & 0.6 & 0.0 & 0.0 \\
\hline In percent of exports of goods and services & 0.0 & 0.2 & 0.3 & 0.2 & 3.7 & 3.9 & 0.6 & 0.0 & 0.0 \\
\hline In percent of gross reserves & 0.0 & 0.5 & 0.6 & 0.6 & 9.9 & 11.4 & 1.7 & 0.0 & 0.0 \\
\hline
\end{tabular}

Source: IMF staff estimates.

1/ End of period. Calculated based on proposed extension and rephasing of purchases. 
Appendix Table 1. Hungary: Public Sector Debt Sustainability Framework, 2006-16

(In percent of GDP, unless otherwise indicated)

\begin{tabular}{|c|c|c|c|c|c|c|c|c|c|c|c|c|}
\hline & \multicolumn{5}{|c|}{ Actual } & \multirow[b]{2}{*}{2011} & \multirow[b]{2}{*}{2012} & \multirow[b]{2}{*}{2013} & \multirow[b]{2}{*}{2014} & \multirow[b]{2}{*}{2015} & \multirow[b]{2}{*}{2016} & \multirow{3}{*}{$\begin{array}{c}\text { Debt-stabilizing } \\
\text { primary } \\
\text { balance } 9 /\end{array}$} \\
\hline & 2006 & 2007 & 2008 & 2009 & 2010 & & & & & & & \\
\hline \multirow{3}{*}{$\begin{array}{l}\text { Baseline: Public sector debt } 1 / \\
\text { o/w foreign-currency denominated }\end{array}$} & & & & & & & & & & & & \\
\hline & 65.8 & 66.1 & 72.3 & 78.4 & 80.2 & 75.8 & 74.3 & 73.2 & 71.4 & 69.5 & 67.7 & 0.3 \\
\hline & 16.1 & 17.3 & 26.1 & 33.4 & 33.6 & 32.3 & 29.7 & 27.4 & 25.1 & 23.6 & 22.8 & \\
\hline Change in public sector debt & 4.0 & 0.3 & 6.2 & 6.1 & 1.8 & -4.4 & -1.5 & -1.1 & -1.8 & -1.9 & -1.9 & \\
\hline Identified debt-creating flows $(4+7+12)$ & 5.6 & -1.9 & -1.6 & 8.6 & 1.4 & 3.8 & -0.3 & -1.1 & -1.8 & -1.9 & -1.9 & \\
\hline Primary deficit $10 /$ & 5.4 & 0.9 & -0.5 & 0.0 & 0.4 & 3.9 & -0.7 & -0.9 & -1.4 & -1.8 & -2.0 & \\
\hline Revenue and grants $10 /$ & 42.7 & 45.0 & 45.2 & 46.0 & 44.4 & 42.3 & 42.4 & 41.6 & 41.8 & 42.0 & 42.2 & \\
\hline Primary (noninterest) expenditure & 48.1 & 45.9 & 44.7 & 46.0 & 44.7 & 46.2 & 41.7 & 40.6 & 40.4 & 40.2 & 40.2 & \\
\hline Automatic debt dynamics $2 /$ & 2.1 & -1.7 & -1.1 & 8.6 & 1.0 & -0.1 & 0.4 & -0.2 & -0.4 & -0.1 & 0.1 & \\
\hline Contribution from interest rate/growth differential $3 /$ & -0.5 & -0.1 & 0.6 & 6.5 & 1.0 & -0.1 & 0.4 & -0.2 & -0.4 & -0.1 & 0.1 & \\
\hline Of which contribution from real interest rate & 1.5 & 0.4 & 1.1 & 1.5 & 1.9 & 1.9 & 2.1 & 1.9 & 1.9 & 2.0 & 2.0 & \\
\hline Of which contribution from real GDP growth & -2.1 & -0.5 & -0.5 & 5.0 & -0.9 & -2.0 & -1.8 & -2.1 & -2.2 & -2.1 & -1.9 & \\
\hline Contribution from exchange rate depreciation 4 / & 2.6 & -1.6 & -1.7 & 2.1 & 5.0 & $\ldots$ & $\ldots$ & $\ldots$ & $\ldots$ & $\ldots$ & $\ldots$ & \\
\hline Other identified debt-creating flows & -1.8 & -1.2 & 0.0 & 0.0 & 0.0 & 0.0 & 0.0 & 0.0 & 0.0 & 0.0 & 0.0 & \\
\hline Privatization receipts (negative) & -1.8 & -1.2 & 0.0 & 0.0 & 0.0 & 0.0 & 0.0 & 0.0 & 0.0 & 0.0 & 0.0 & \\
\hline Recognition of implicit or contingent liabilities & 0.0 & 0.0 & 0.0 & 0.0 & 0.0 & 0.0 & 0.0 & 0.0 & 0.0 & 0.0 & 0.0 & \\
\hline Other (specify, e.g. bank recapitalization) & 0.0 & 0.0 & 0.0 & 0.0 & 0.0 & 0.0 & 0.0 & 0.0 & 0.0 & 0.0 & 0.0 & \\
\hline Residual, including asset changes (2-3) 5/ & -1.7 & 2.2 & 7.8 & -2.5 & 0.4 & -8.2 & -1.2 & 0.0 & 0.0 & 0.0 & 0.0 & \\
\hline Public sector debt-to-revenue ratio $1 /$ & 154.1 & 146.9 & 160.1 & 170.5 & 180.8 & 179.1 & 175.3 & 176.0 & 171.0 & 165.6 & 160.3 & \\
\hline Gross financing need 6 / & 24.9 & 19.1 & 17.1 & 18.4 & 18.0 & 16.4 & 12.5 & 18.6 & 17.0 & 14.4 & 14.9 & \\
\hline in billions of U.S. dollars & 28.1 & 26.4 & 26.8 & 23.8 & 23.4 & 22.7 & 18.0 & 28.3 & 27.2 & 24.3 & 26.3 & \\
\hline Scenario with key variables at their historical averages 71 & & & & & & 75.8 & 76.7 & 78.8 & 80.8 & 82.8 & 84.8 & -1.8 \\
\hline Scenario with no policy change (constant primary balance) in 2010-2016 & & & & & & 75.8 & $\mathbf{7 8 . 9}$ & 82.6 & 86.1 & 89.9 & $\mathbf{9 4 . 0}$ & 0.4 \\
\hline \multicolumn{13}{|l|}{ Key Macroeconomic and Fiscal Assumptions Underlying Baseline } \\
\hline Real GDP growth (in percent) & 3.6 & 0.8 & 0.8 & -6.7 & 1.2 & 2.6 & 2.5 & 3.0 & 3.2 & 3.1 & 2.8 & \\
\hline Average nominal interest rate on public debt (in percent) $8 /$ & 6.9 & 6.6 & 6.6 & 6.1 & 5.5 & 5.1 & 5.5 & 5.7 & 5.8 & 5.9 & 5.9 & \\
\hline Average real interest rate (nominal rate minus change in GDP deflator, in percent) & 2.8 & 0.7 & 1.8 & 1.7 & 2.6 & 2.6 & 3.0 & 2.8 & 2.8 & 3.0 & 3.1 & \\
\hline Nominal appreciation (increase in US dollar value of local currency, in percent) & -15.6 & 11.5 & 11.0 & -7.0 & -13.2 & $\ldots$ & $\ldots$ & & $\ldots$ & & & \\
\hline Inflation rate (GDP deflator, in percent) & 4.1 & 5.9 & 4.8 & 4.4 & 2.9 & 2.6 & 2.5 & 2.9 & 3.0 & 2.8 & 2.8 & \\
\hline Growth of real primary spending (deflated by GDP deflator, in percent) & 8.4 & -3.8 & -1.8 & -4.0 & -1.6 & 6.0 & -7.5 & 0.3 & 2.6 & 2.7 & 2.8 & \\
\hline Primary deficit $10 /$ & 5.4 & 0.9 & -0.5 & 0.0 & 0.4 & 3.9 & -0.7 & -0.9 & -1.4 & -1.8 & -2.0 & \\
\hline \multicolumn{13}{|l|}{ Memorandum item } \\
\hline Growth of real public debt & 11.1 & 0.6 & 4.0 & 0.0 & 2.2 & -4.2 & -0.1 & 1.3 & 0.7 & 0.2 & -0.1 & \\
\hline
\end{tabular}

1/ General government gross debt.

2/ Derived as $[(r-\pi(1+g)-g+\alpha \varepsilon(1+r)] /(1+g+\pi+g \pi))$ times previous period debt ratio, with $r=$ interest rate; $\pi=$ growth rate of GDP deflator; $g=$ real GDP growth rate; $\alpha=$ share of foreign-currency

denominated debt; and $\varepsilon=$ nominal exchange rate depreciation (measured by increase in local currency value of U.S. dollar).

$3 /$ The real interest rate contribution is derived from the denominator in footnote $2 /$ as $\mathrm{r}-\pi(1+\mathrm{g})$ and the real growth contribution as -9

The exchange rate contribution is derived from the numerator in footnote $2 /$ as $\alpha \varepsilon(1+r)$.

For projections, this line includes exchange rate changes. The large residual in 2011 is explained by the transfer of private pension assets to the public sector.

6/ Defined as public sector deficit, plus amortization of medium and long-term public sector debt, plus short-term debt at end of previous period.

7/ The key variables include real GDP growth; real interest rate; and primary balance in percent of GDP.

/ Derived as nominal interest expenditure divided by previous period debt stock.

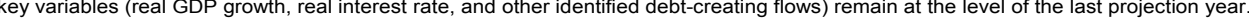

/ Excludes revenues from the transfer of pension assets. 


\section{Appendix Figure 1. Hungary: Public Debt Sustainability: Bound Tests 1/ (Public debt in percent of GDP)}

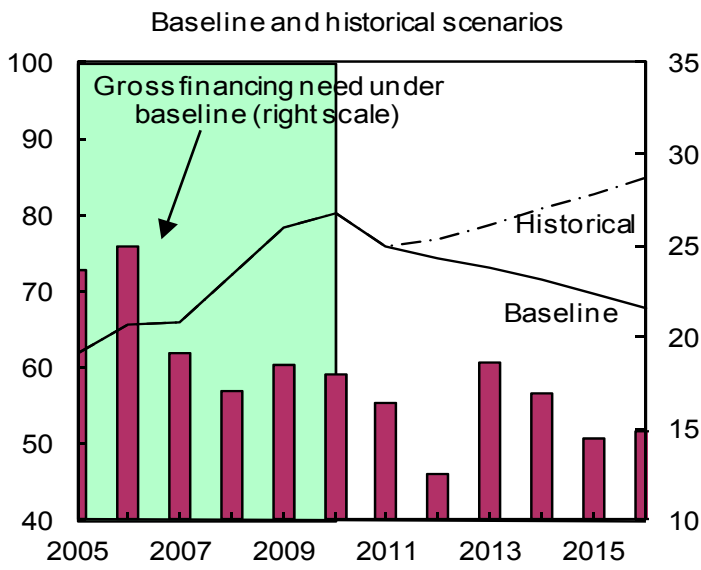

Growth shock (in percent per year)

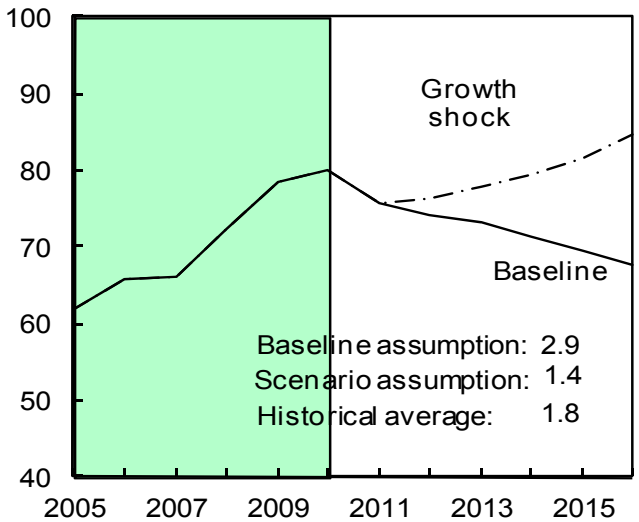

Combined shock 2/

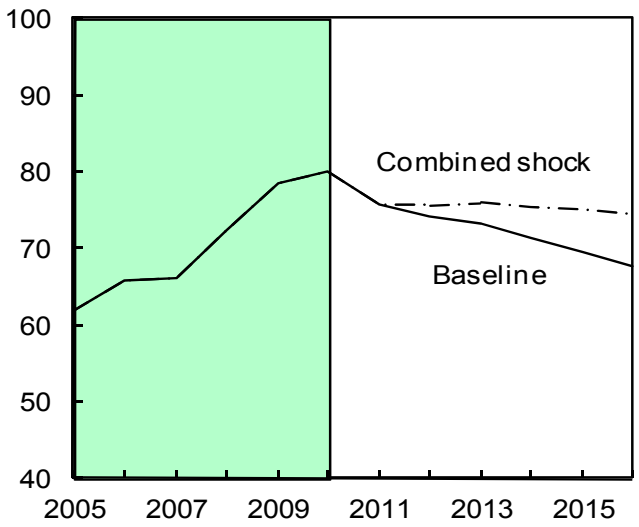

In terest rate shock (in percent)

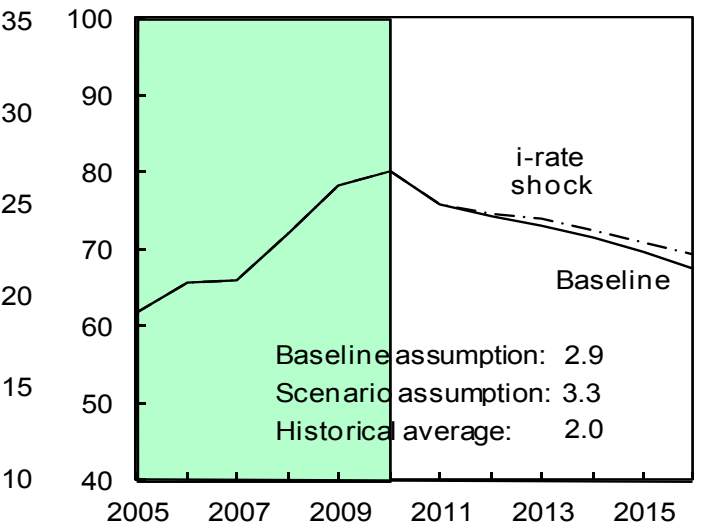

Primary balan ce shock (in percent of GDP) and no policy change scenario (constant primary balance)

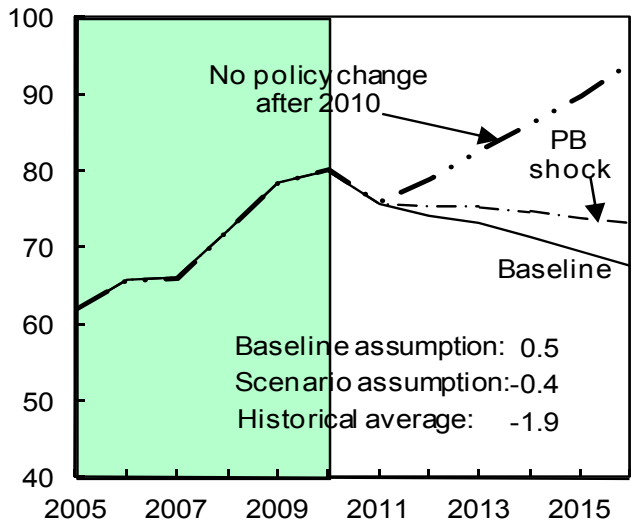

Real depreciation and contingent liabilities shocks $3 /$

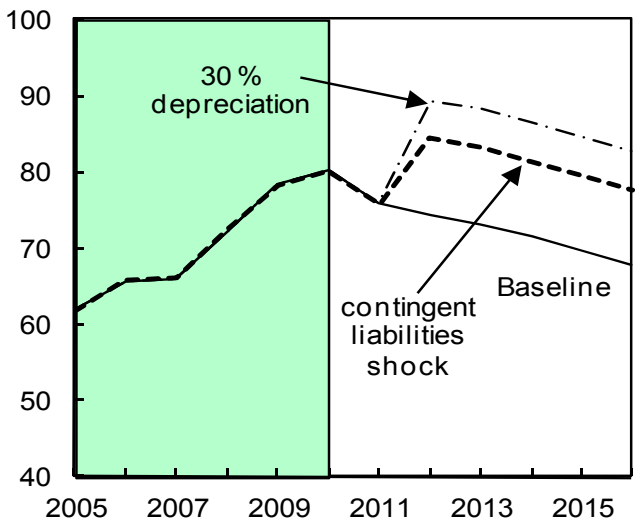

Sources: International Monetary Fund, country desk data, and staff estimates.

1/Shaded areas represent actual data. In dividual shocks are permanent one-half standard deviation shocks.

Figures in the boxes represent average projections for the respective variables in the baseline and scenario being presented. Ten-year historical average for the variable is also shown.

2/ Permanent 1/4 standard deviation shocks ap plied to real interest rate, growth rate, and primary balance. $3 /$ One-time real depreciation of 30 percent and 10 percent of GDP shock to contingent liabilities occur in 2009 , with real depreciation defined as nominal depreciation (measured by percentage fall in d ollar value of local curren cy) minus d omestic inflation (based on GDP deflator). 
Appendix Table 2. Hungary: External Debt Sustainability Framework, 2006-16

(In percent of GDP, unless otherwise indicated) 1/

\begin{tabular}{|c|c|c|c|c|c|c|c|c|c|c|c|c|}
\hline & \multicolumn{5}{|c|}{ Actual } & \multicolumn{7}{|c|}{ Projections } \\
\hline & 2006 & 2007 & 2008 & 2009 & 2010 & 2011 & 2012 & 2013 & 2014 & 2015 & 2016 & \multirow{2}{*}{$\begin{array}{c}\text { Debt-stabilizing } \\
\text { non-interest } \\
\text { current account } 7 \text { । } \\
-4.9\end{array}$} \\
\hline Baseline: External debt & 96.5 & 103.2 & 116.0 & 146.6 & 139.8 & 139.0 & 131.0 & 122.8 & 117.7 & 113.2 & 109.4 & \\
\hline Change in external debt & 8.8 & 6.7 & 12.8 & 30.6 & -6.8 & -0.8 & -8.0 & -8.2 & -5.1 & -4.5 & -3.8 & \\
\hline Identified external debt-creating flows $(4+8+9)$ & 3.2 & 1.9 & 0.5 & 13.2 & -11.1 & -7.1 & -7.7 & -7.8 & -6.3 & -5.1 & -4.1 & \\
\hline Current account deficit, excluding interest payments & 4.4 & 3.2 & 1.9 & -5.7 & -7.0 & -7.9 & -7.5 & -5.8 & -4.1 & -2.9 & -2.2 & \\
\hline Deficit in balance of goods and services & 1.4 & -0.9 & -0.4 & -5.1 & -7.2 & -7.8 & -9.0 & -7.3 & -5.8 & -5.0 & -4.5 & \\
\hline Exports & 77.1 & 80.3 & 81.3 & 77.2 & 86.6 & 92.9 & 98.0 & 101.3 & 104.4 & 108.0 & 112.3 & \\
\hline Imports & 78.5 & 79.4 & 80.9 & 72.1 & 79.3 & 85.0 & 89.0 & 94.0 & 98.6 & 103.0 & 107.7 & \\
\hline Net non-debt creating capital inflows (negative) $2 /$ & -2.4 & 4.6 & -1.3 & -0.6 & -1.8 & -2.0 & -2.9 & -3.8 & -3.9 & -3.8 & -3.7 & \\
\hline Net foreign direct investment, equity & 3.4 & 0.9 & 3.6 & 0.7 & 2.4 & 2.0 & 2.4 & 3.3 & 3.4 & 3.4 & 3.3 & \\
\hline Net portfolio investment,equity & -0.9 & -5.5 & -2.3 & -0.1 & -0.6 & 0.0 & 0.4 & 0.5 & 0.5 & 0.4 & 0.4 & \\
\hline Automatic debt dynamics $3 /$ & 1.3 & -5.8 & -0.2 & 19.5 & -2.3 & 2.7 & 2.6 & 1.9 & 1.6 & 1.6 & 1.8 & \\
\hline Contribution from nominal interest rate & 3.5 & 3.7 & 5.4 & 5.3 & 4.9 & 6.2 & 5.9 & 5.6 & 5.4 & 5.1 & 4.8 & \\
\hline Contribution from real GDP growth & -2.9 & -0.7 & -0.8 & 8.9 & -1.7 & -3.5 & -3.3 & -3.7 & -3.7 & -3.4 & -3.0 & \\
\hline Contribution from price and exchange rate changes $4 /$ & 0.6 & -8.9 & -4.7 & 5.3 & -5.5 & $\ldots$ & $\ldots$ & $\ldots$ & $\ldots$ & $\ldots$ & $\ldots$ & \\
\hline Residual, incl. change in gross foreign assets (2-3) 5/ & 5.6 & 4.7 & 12.3 & 17.4 & 4.4 & 6.3 & -0.3 & -0.4 & 1.2 & 0.6 & 0.3 & \\
\hline External debt-to-exports ratio (in percent) & 125.2 & 128.5 & 142.7 & 189.9 & 161.5 & 149.7 & 133.7 & 121.3 & 112.8 & 104.9 & 97.5 & \\
\hline Gross external financing need (in billions of euros) 6 / & 28.7 & 30.9 & 35.7 & 34.4 & 37.6 & 42.7 & 45.1 & 48.5 & 54.0 & 51.7 & 55.9 & \\
\hline in percent of GDP & 32.0 & 30.6 & 33.5 & 37.0 & 38.4 & 42.3 & 42.5 & 43.1 & 45.2 & 40.8 & 41.7 & \\
\hline Scenario with key variables at their historical averages $7 /$ & & & & & & 139.0 & 136.9 & 135.1 & 134.6 & 133.2 & 131.4 & -6.7 \\
\hline \multicolumn{13}{|l|}{ Key Macroeconomic Assumptions Underlying Baseline 8/ } \\
\hline Real GDP growth (in percent) & 3.3 & 0.8 & 0.8 & -6.7 & 1.2 & 2.6 & 2.5 & 3.0 & 3.2 & 3.1 & 2.8 & \\
\hline GDP deflator in euros (change in percent) & -1.9 & 11.3 & 4.8 & -6.5 & 4.2 & 0.6 & 2.5 & 2.9 & 3.0 & 2.8 & 2.8 & \\
\hline Nominal external interest rate (in percent) & 4.1 & 4.3 & 5.5 & 4.0 & 3.5 & 4.6 & 4.5 & 4.5 & 4.6 & 4.6 & 4.5 & \\
\hline Growth of exports (euro terms, in percent) & 15.4 & 16.9 & 6.9 & -17.2 & 18.2 & 10.7 & 10.8 & 9.5 & 9.6 & 9.7 & 9.9 & \\
\hline Growth of imports (euro terms, in percent) & 14.7 & 13.6 & 7.7 & -22.3 & 16.0 & 10.6 & 9.9 & 11.9 & 11.6 & 10.7 & 10.5 & \\
\hline Current account balance, excluding interest payments & -4.4 & -3.2 & -1.9 & 5.7 & 7.0 & 7.9 & 7.5 & 5.8 & 4.1 & 2.9 & 2.2 & \\
\hline Net non-debt creating capital inflows & 2.4 & -4.6 & 1.3 & 0.6 & 1.8 & 2.0 & 2.9 & 3.8 & 3.9 & 3.8 & 3.7 & \\
\hline
\end{tabular}

Net non-debt creating capital inflows

1/ Excluding Special Purpose Entities. Including inter-company loans and nonresidents' holdings of forint-denominated assets.

2/ Includes EU capital transfers.

$3 /$ Derived as $[r-g-\rho(1+g)+\varepsilon \alpha(1+r)] /(1+g+\rho+g \rho)$ times previous period debt stock, with $r=$ nominal effective interest rate on external debt; $\rho=$ change in domestic GDP deflator in euro terms, $g=$ real GDP growth rate, $\varepsilon=$ nominal appreciation (increase in dollar value of domestic currency), and $\alpha=$ share of domestic-currency denominated debt in total external debt.

$4 /$ The contribution from price and exchange rate changes is defined as $[-\rho(1+g)+\varepsilon \alpha(1+r)] /(1+g+\rho+g \rho)$ times previous period debt stock. $\rho$ increases with an appreciating domestic currency $(\varepsilon>0)$ and rising inflation (based on GDP deflator).

$5 /$ For projection, line includes the impact of price and exchange rate changes.

6/ Defined as current account deficit, plus amortization on medium- and long-term debt, plus short-term debt at end of previous period.

7/ The key variables include real GDP growth; nominal interest rate; dollar deflator growth; and both non-interest current account and non-debt inflows in percent of GDP.

8/ Long-run, constant balance that stabilizes the debt ratio assuming that key variables (real GDP growth, nominal interest rate, dollar deflator growth, and non-debt inflows in percent of GDP) remain at their levels

of the last projection year.

\section{(C) International Monetary Fund. Not for Redistribution}




\section{Appendix Figure 2. Hungary: External Debt Sustainability: Bound Tests 1/} (External debt in percent of GDP)

Baseline and historical scenarios

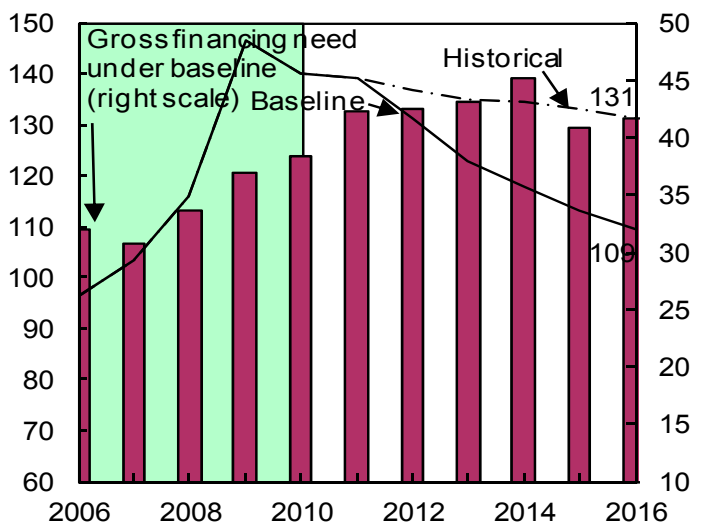

Growth shock (in percent per year)

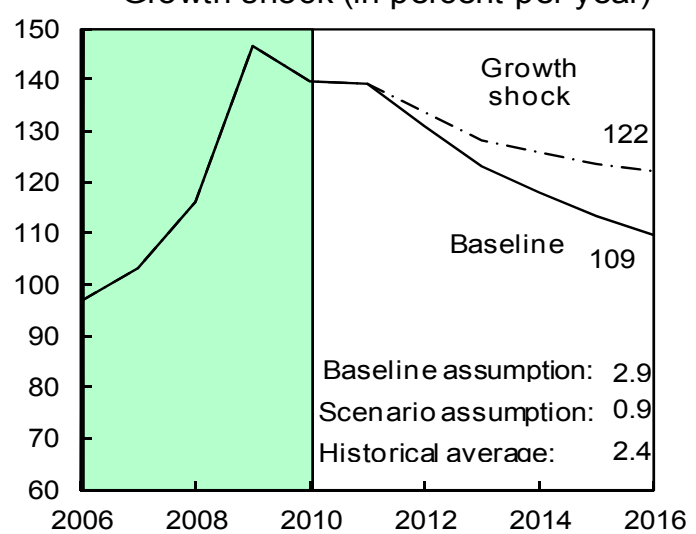

Combined shock 2/

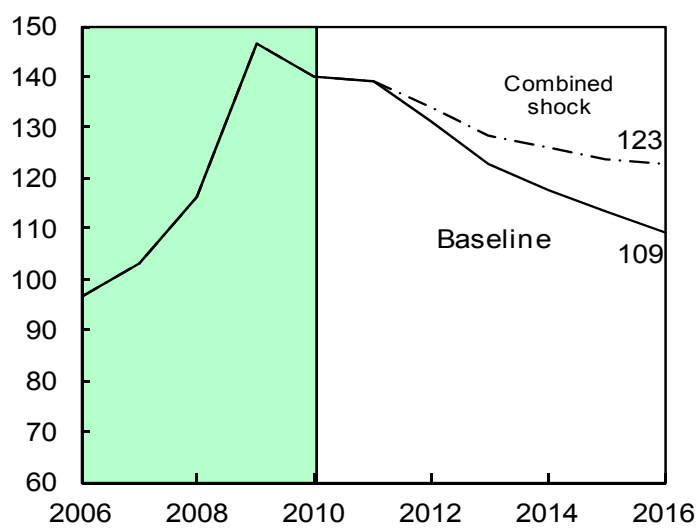

Interest rate shock (in percent)

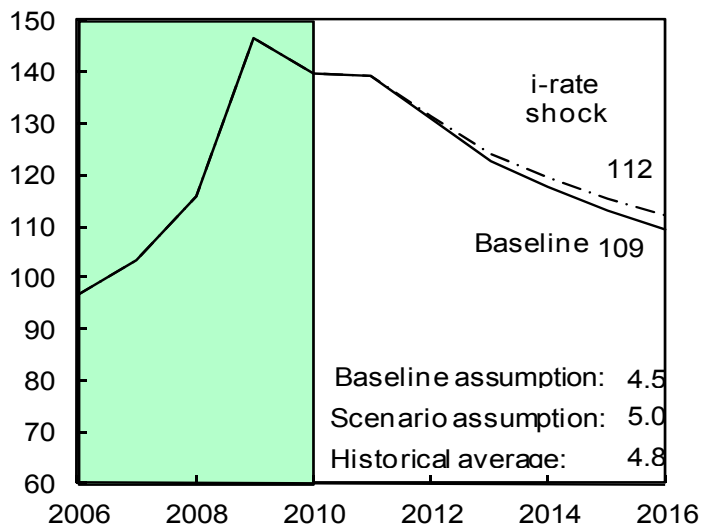

Non-interest current account shock (in percent of GDP)

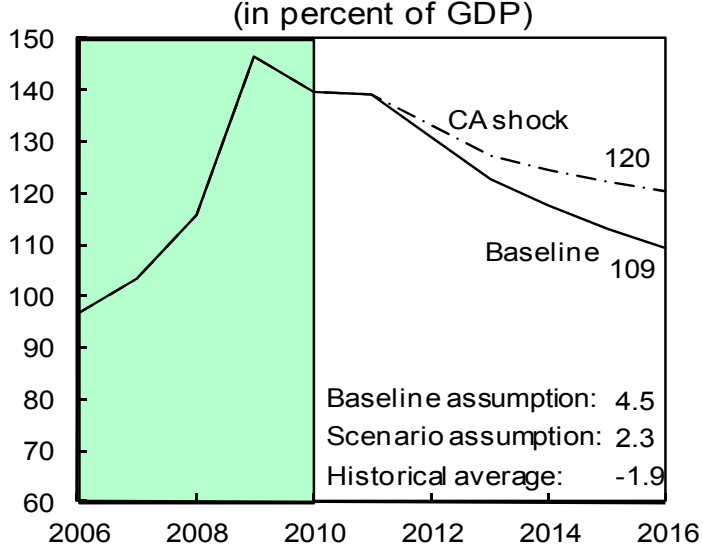

Real depreciation shock 3/

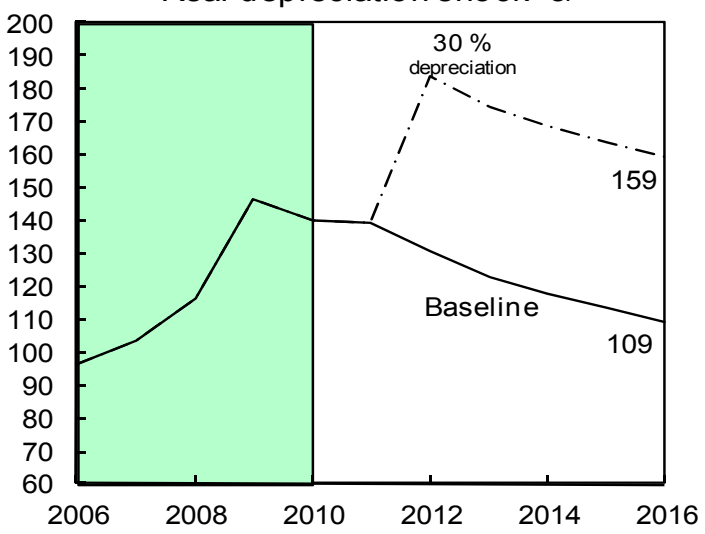

Sources: International Monetary Fund, Country desk data, and staff estimates.

$1 /$ Shaded areas represent actual data. Individual shocks are permanent one-half standard deviation shocks. Figures in the boxes represent average projections for the respective variables in the baseline and scenario being presented. Ten-year historical average for the variable is also shown. 2/Permanent $1 / 4$ standard deviation shocks applied to real interest rate, growth rate, and current account balance.

3/One-time real depreciation of 30 percent occurs in 2011. 
INTERNATIONAL MONETARY FUND

\section{HUNGARY}

First Post-Program Monitoring Discussions-Informational Annex

Prepared by the European Department

June 3, 2011

Contents

Page

Appendix

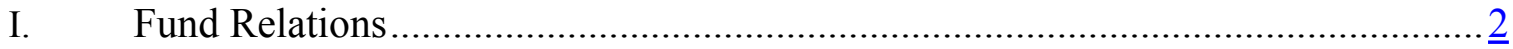

II. Statistical Issues....................................................................................... 


\section{APPENDIX I. HUNGARY: FUND RELATIONS}

(As of March 31, 2011)

I. Membership Status: Joined on May 6, 1982; Article VIII.

II. General Resources Account:

$\begin{array}{cr}\text { SDR Million } & \begin{array}{r}\text { Percent } \\ \text { of Quota }\end{array} \\ 1,038.40 & 100.00 \\ 8,601.57 & 828.35 \\ 73.83 & 7.11 \\ & \text { Percent of } \\ \text { SDR Million } & \begin{array}{c}\text { Allocation } \\ 991.05\end{array} \\ 700.45 & 700.00 \\ \end{array}$

IV. Outstanding Purchases and Loans:

SDR Million of Quota

Stand-By Arrangements

$7,637.00$

735.46

V. Financial Arrangements:

$\begin{array}{lcccc}\text { Type } & \begin{array}{c}\text { Date of } \\ \text { Arrangement }\end{array} & \begin{array}{c}\text { Expiration } \\ \text { Date }\end{array} & \begin{array}{c}\text { Amount } \\ \text { Approved } \\ \text { (SDR Million) }\end{array} & \begin{array}{c}\text { Amount } \\ \text { Drawn } \\ \text { (SDR Million) }\end{array} \\ \text { Stand-by } & 11 / 6 / 08 & 10 / 5 / 10 & 10,537.50 & 7,637.00 \\ \text { Stand-by } & 3 / 15 / 96 & 2 / 14 / 98 & 264.18 & 0.00 \\ \text { Stand-by } & 9 / 15 / 93 & 12 / 14 / 94 & 340.00 & 56.70\end{array}$

VI. Projected Payments to Fund: (SDR million; based on existing use of resources and present holdings of SDRs)

\begin{tabular}{lrrrrr} 
& \multicolumn{5}{c}{ Forthcoming } \\
\cline { 2 - 6 } & 2011 & 2012 & 2013 & 2014 & 2015 \\
\hline & & & & & \\
Principal & & $3,220.19$ & $3,818.50$ & 598.31 & \\
Charges/Interest & 152.13 & 180.02 & 67.48 & 6.79 & 1.37 \\
Total & 152.13 & $3,400.21$ & $3,885.98$ & 605.11 & 1.37
\end{tabular}

VII. Exchange Rate Arrangement:

The de facto exchange rate arrangement for the Hungarian forint is floating, effective November 1st, 2008. 
VIII. Article IV Consultations:

Hungary is on a 12-month consultation cycle. The last Article IV Board discussion took place on January 31, 2011. The associated Executive Board assessment is available at http://www.imf.org/external/np/sec/pn/2011/pn1115.htm and the staff report at http://www.imf.org/external/pubs/cat/longres.aspx?sk=24614.0. Hungary has accepted the obligations of Article VIII and maintains an exchange rate system free of restrictions on the making of payments and transfers on current international transactions except for those maintained solely for the preservation of national or international security and that have been notified to the Fund pursuant to Executive Board Decision No. 144-(52/51).

IX. Technical Assistance:

\begin{tabular}{llll}
\hline Year & Department. & Purpose & Date \\
\hline 2007 & FAD & Tax policy & April \\
2007 & FAD & Public financial management & June \\
2007 & FAD & Tax administration & October \\
2008 & FAD & Pension reform & May \\
2008 & FAD & Tax administration & October \\
2009 & FAD & Tax administration & March \\
2009 & MCM & Banking Supervision & July \\
2009 & FAD & Tax administration & August \\
2009 & LEG & Bank resolution framework & September \\
2009 & FAD & Tax administration & November \\
2010 & FAD & Expenditure Rationalization & June \\
2010 & MCM & Macro Modeling & July \\
2010 & FAD & Tax Revenue Forecasting & September \\
2010 & MCM & Macro Modeling & November \\
\hline
\end{tabular}

X. Resident Representative: Ms. Iryna Ivaschenko assumed her duties on May 1, 2009. 
APPENDIX II. HUNGARY-STATISTICAL ISSUES

As of June 3, 2011

\section{ASSESSMENT OF DATA ADEQUACY FOR SURVEILLANCE}

General: Data provision is adequate for surveillance

Government Finance Statistics: Data reporting on fiscal accounting needs to be improved further. The monthly cash-basis accounts of the central government prepared by the Ministry of Finance and National Economy do not reflect the GFS presentation. This complicates staff's ability to analyze trends and to appropriately anticipate the impact on general government accounts. Data on revenue and expenditure arrears has been redily provided by the authorities upon request, but provision of this data on an automaticbasis would facilitate the monitoring of obligations on an accrual basis.

Similarly, automatic provision of local government revenues and expenditures, as well as of financial statements of state-owned enterprises (an important source of contingent liabilities), would allow for closer regular monitoring of the general government. Currently, in the absence of a specific request for this information, local government finances can only be monitored from the financing flows as compiled by the central bank.

\section{DATA STANDARDS AND QUALITY}

Subscriber to the Fund's Special Data

Dissemination Standard (SDDS) since May, 1996
Hungary published its original ROSC Data Module in 2001 and updates are available on the IMF internet web site. The latest update is Hungary: Report on the Observance of Standards and Codes-Data Module, 2004 Update (July 2004). 


\section{Hungary: Table of Common Indicators Required for Surveillance}

As June 3, 2011

\begin{tabular}{|c|c|c|c|c|c|c|c|}
\hline & \multirow{2}{*}{$\begin{array}{l}\text { Date of latest } \\
\text { observation }\end{array}$} & \multirow{2}{*}{$\begin{array}{l}\text { Date } \\
\text { received }\end{array}$} & \multirow{2}{*}{$\begin{array}{l}\text { Frequency } \\
\text { of } \\
\text { Data }^{7}\end{array}$} & \multirow{2}{*}{$\begin{array}{l}\text { Frequency of } \\
\text { Reporting }^{7}\end{array}$} & \multirow{2}{*}{$\begin{array}{l}\text { Frequency of } \\
\text { publication }\end{array}$} & \multicolumn{2}{|c|}{ Memo Items: } \\
\hline & & & & & & $\begin{array}{c}\text { Data Quality - } \\
\text { Methodological soundness }^{8}\end{array}$ & $\begin{array}{l}\text { Data Quality Accuracy } \\
\text { and reliability }\end{array}$ \\
\hline Exchange Rates & $5 / 11 / 2011$ & $5 / 11 / 2011$ & $\mathrm{D}$ and $\mathrm{M}$ & $\mathrm{D}$ and $\mathrm{M}$ & $\mathrm{D}$ and $\mathrm{M}$ & & \\
\hline $\begin{array}{l}\text { International Reserve Assets and } \\
\text { Reserve Liabilities of the Monetary } \\
\text { Authorities }\end{array}$ & Mar 2011 & $4 / 18 / 2011$ & $\mathrm{M}$ & $\mathrm{M}$ & $M$ & & \\
\hline Reserve/Base Money & Mar 2011 & $4 / 29 / 2011$ & $\mathrm{M}$ & $M$ & $\mathrm{M}$ & \multirow[t]{4}{*}{$\mathrm{O}, \mathrm{O}, \mathrm{LO}, \mathrm{LO}$} & \multirow[t]{4}{*}{$\mathrm{O}, \mathrm{O}, \mathrm{O}, \mathrm{O}, \mathrm{LO}$} \\
\hline Broad Money & Mar 2011 & $4 / 29 / 2011$ & $\mathrm{M}$ & $\mathrm{M}$ & $\mathrm{M}$ & & \\
\hline Central Bank Balance Sheet & Mar 2011 & $4 / 29 / 2011$ & $M$ & $\mathrm{M}$ & $\mathrm{M}$ & & \\
\hline $\begin{array}{l}\text { Consolidated Balance Sheet of the } \\
\text { Banking System }\end{array}$ & Mar 2011 & $4 / 29 / 2011$ & $\mathrm{M}$ & $\mathrm{M}$ & $\mathrm{M}$ & & \\
\hline Interest Rates $^{2}$ & Apr 2011 & $5 / 5 / 2011$ & $\mathrm{M}$ & $\mathrm{M}$ & $\mathrm{M}$ & & \\
\hline Consumer Price Index & Apr 2011 & $5 / 11 / 2011$ & $\mathrm{M}$ & $\mathrm{M}$ & $\mathrm{M}$ & $\mathrm{O}, \mathrm{O}, \mathrm{O}, \mathrm{O}$ & $\mathrm{O}, \mathrm{O}, \mathrm{O}, \mathrm{O}, \mathrm{NA}$ \\
\hline $\begin{array}{l}\text { Revenue, Expenditure, Balance and } \\
\text { Composition of Financing }{ }^{3}-\text { General } \\
\text { Government }^{4}\end{array}$ & 2010 & $4 / 26 / 2011$ & $A$ & $\mathrm{~A}$ & $A$ & \multirow[t]{2}{*}{$\mathrm{O}, \mathrm{LNO}, \mathrm{LO}, \mathrm{O}$} & \multirow[t]{2}{*}{ LO,O,O,O,NA } \\
\hline $\begin{array}{l}\text { Revenue, Expenditure, Balance and } \\
\text { Composition of Financing }{ }^{3}-\text { Central } \\
\text { Government }\end{array}$ & Mar 2011 & $4 / 19 / 2011$ & $\mathrm{M}$ & $\mathrm{M}$ & $\mathrm{M}$ & & \\
\hline $\begin{array}{l}\text { Stocks of Central Government and } \\
\text { Central Government-Guaranteed Debt }{ }^{5}\end{array}$ & Q4 2010 & $4 / 1 / 2011$ & $Q$ & $Q$ & $Q$ & & \\
\hline External Current Account Balance & Q4 2010 & $3 / 31 / 2011$ & $Q$ & Q & $Q$ & \multirow[t]{2}{*}{ O,LO,LO,LO } & \multirow[t]{2}{*}{$\mathrm{O}, \mathrm{O}, \mathrm{O}, \mathrm{O}, \mathrm{NA}$} \\
\hline $\begin{array}{l}\text { Exports and Imports of Goods and } \\
\text { Services }\end{array}$ & Q4 2010 & $3 / 31 / 2011$ & Q & $Q$ & $Q$ & & \\
\hline GDP/GNP & Q4 2010 & $3 / 11 / 2011$ & $Q$ & $Q$ & $Q$ & $\mathrm{O}, \mathrm{O}, \mathrm{O}, \mathrm{LO}$ & $\mathrm{O}, \mathrm{LO}, \mathrm{O}, \mathrm{O}, \mathrm{NA}$ \\
\hline Gross External Debt & Q4 2010 & $3 / 31 / 2011$ & $Q$ & $Q$ & $Q$ & & \\
\hline International investment Position $^{6}$ & Q4 2010 & $3 / 31 / 2011$ & & & & & \\
\hline
\end{tabular}

${ }^{1}$ Includes reserve assets pledged or otherwise encumbered as well as net derivative positions.

${ }^{2}$ Both market-based and officially-determined, including discount rates, money market rates, rates on treasury bills, notes and bonds.

${ }^{3}$ Foreign, domestic bank, and domestic nonbank financing.

${ }^{4}$ The general government consists of the central government (budgetary funds, extra budgetary funds, and social security funds) and state and local governments.

${ }^{5}$ Including currency and maturity composition.

${ }^{6}$ Includes external gross financial asset and liability positions vis-à-vis nonresidents.

${ }^{7}$ Daily (D), Weekly (W), Monthly (M), Quarterly (Q), Annually (A); Irregular (I); Not Available (NA).

${ }^{8}$ Reflects the assessment provided in the data ROSC and Substantive Update published in May 2001 and July 2004, respectively, and based on the findings of the respective missions that took place during January 2001 and January 2004 for the

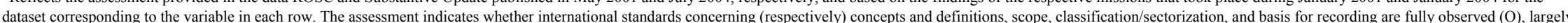
observed (LO), largely not observed (LNO), or not observed (NO).

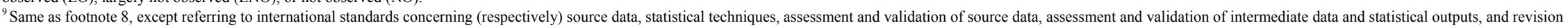
studies. 


\section{Statement by the IMF Staff Representative on Hungary \\ Executive Board Meeting \\ June 8, 2011}

This statement provides information that has become available since the issuance of the staff report (EBS/11/75). The new information does not alter the thrust of the staff appraisal.

1. The macroeconomic environment is broadly unchanged from the staff report. The flash estimate for first quarter GDP growth was 0.7 percent qoq which is consistent with staff's forecast of 2.6 percent annual growth in 2011. Domestic demand remains weak with retail sales falling 2.4 percent in March but strong demand from Germany helped exports rise 23 percent, driving the trade balance to a record surplus of 6 percent of GDP. On fiscal policy, the budget deficit through April continues to appear consistent with the authorities' revised fiscal target for 2011. Food prices pushed annual inflation to 4.4 percent in April, but muted core prices and weak domestic demand data have left the MNB on hold since January. Risk spreads, at about 250 basis points, are largely unchanged since the staff report.

\section{Implementation of the Szell Kalman plan is proceeding gradually, with many} details yet to be determined. Thus far, measures have been fully identified in the area of sick pay. In addition, Parliament is considering proposals to revise drug subsidies and increase taxes for pharmaceutical companies. Furthermore, a constitutional amendment has been proposed enabling the revision of early retirement schemes. According to the authorities' timetable, additional measures on pension, health care and employment are expected to be specified by July 1, although final details regarding 2012 measures and their fiscal impact may not realistically emerge until the budget process in the fall.

3. The government has reached an agreement with the banking sector designed to reduce stress in FX-mortgage portfolios. While broadly consistent with the pillars identified in Box 3 of the staff report, several key parameters in the final agreement have changed that materially alter the implications of the agreement:

- $\quad$ The exchange rate for calculating monthly installments is fixed for four years at levels stronger than initially expected (i.e. 250 for EUR/HUF, 180 for CHF/HUF, and 2 for JPY/HUF) and no means-testing has been specified, raising concerns about moral hazard, potential fiscal cost and household balance sheets once the temporary fix expires.

- The foreclosure and eviction moratoria will be lifted only very gradually, which will likely prevent banks from fully cleaning balance sheets of existing NPLs even over the medium term. 
- While the de facto ban on EUR loans will be lifted, the authorities have introduced particularly stringent prudential requirements regarding minimum euro denominated income that will leave FX borrowing effectively out of reach for most of the population; the de facto ban on CHF mortgage lending remains in place.

- $\quad$ The plan to introduce an interest rate subsidy remains, but the entire concept has changed to target defaulted borrowers willing to downsize to a less valuable accommodation (and a smaller loan).

- In addition to participating in real estate purchases, the national asset management fund will invest in social housing. Details of national asset management fund's operation, including eligibility criteria, still need to be determined.

The government has not yet released estimates of the new scheme's fiscal costs.

4. On May 24, the government announced the purchase of a 21 percent stake in Hungarian energy company MOL for EUR $1.88 \mathrm{bn}$, implying some reduction in already modest official reserve coverage. The transaction will be financed by a drawdown in government deposits at the Central Bank, with a corresponding fall in FX reserves to about EUR 36.5 billion at end-2011. While this level is adequate relative to imports, broad money, and the composite metric elaborated in Assessing Reserve Adequacy, coverage of short-term debt will fall from 82 percent to 78 percent. At least in the short term, the MOL purchase thus reduces fiscal and external buffers - already assessed by staff as modest in view of ongoing tensions in the European financial system and large external amortizations falling due in 2012-14. 


\section{INTERNATIONAL MONETARY FUND}

EXTERNAL

Public Information Notice

RELATIONS

DEPARTMENT

Public Information Notice (PIN) No. 11/73

FOR IMMEDIATE RELEASE

June 15, 2011

International Monetary Fund

$70019^{\text {th }}$ Street, NW

Washington, D. C. 20431 USA

\section{IMF Executive Board Concludes First Post-Program Monitoring Discussions and the Ex-Post Evaluation of Exceptional Access under the 2008 Stand-By Arrangement with Hungary}

On June 8, 2011, the Executive Board of the International Monetary Fund (IMF) concluded the First Post-Program Monitoring Discussions and the Ex-Post Evaluation of Exceptional Access under the 2008 Stand-By Arrangement with Hungary. ${ }^{1}$

\section{Background}

The Hungarian economy is slowly rebounding from the global economic crisis. After contracting nearly 7 percent in 2009, real GDP rose 1.2 percent in 2010, due to strong export growth. Meanwhile, domestic demand has remained muted amid a limited recovery in credit, wages, and employment. In this context, the external adjustment has continued, with the current account balance reaching a surplus of over 2 percent in 2010-a substantial change from the large deficits recorded during much of the past decade.

The Central Bank began a tightening cycle in late 2010, ultimately increasing the policy rate by 75 bps before pausing at 6 percent. The hike in rates largely reflected above-target inflation forecasts during the relevant horizon period. However, even though headline inflation has continued to rise due to shocks to food prices, growth in underlying market prices and wages has remained contained, suggesting ongoing spare capacity in the economy and less risk to the medium term inflation target than initially envisioned.

Fiscal policy turned accommodative in 2010. The general government deficit of 4.2 percent exceeded its target by 0.4 percentage points and resulted in a widening in the structural balance by $13 / 4$ percent of potential GDP. The underlying deficit is expected to weaken further

\footnotetext{
${ }^{1}$ Post-Program Monitoring provides for more frequent consultations between the Fund and members whose arrangement has expired but that continue to have Fund credit outstanding, with a particular focus on policies that have a bearing on external viability. There is a presumption that members whose credit outstanding exceeds 200 percent of quota would engage in Post-Program Monitoring.
} 
in 2011. However, large one-off revenues from the transfer of second pillar pension assets to the government will allow the headline fiscal balance to be in surplus and public debt to fall considerably. Going forward, the authorities have announced measures to implement roughly 3 percent of GDP in adjustment over the course of 2012-13, which, if implemented in full, should allow the debt-to-GDP ratio to fall over the medium term.

The financial sector has generally shown resilience due to increased financing from parent banks, which helped subsidiaries increase liquidity and capital buffers during the crisis. However, obstacles remain, particularly because roughly 17 percent of GDP in household credit is denominated in the Swiss franc, which has appreciated considerably during the last year, making loan repayment more difficult. Furthermore, the foreclosure moratorium continues to prevent banks from cleaning balance sheets while the bank levy has lately induced parent banks to deleverage their exposure to Hungary. As a result of these challenges, credit growth is expected to remain subdued in 2011.

Looking forward, economic growth is expected to remain below its medium term potential during the coming two years. Structural bottlenecks in the financial sector and notable fiscal adjustment starting in 2012 are expected to hold back the recovery in domestic demand. Nonetheless, increasing export capacity and strong demand from Germany will allow GDP growth to rise to about $2 \frac{1}{2}$ percent this year and next. In this context, the current account is projected to be in surplus until above-potential growth begins in 2013. A key risk to the economy is that significant vulnerabilities remain, notably high public and external debt, a demanding sovereign amortization schedule, and large currency mismatches.

\section{Executive Board Assessment}

Executive Directors noted that Hungary's economic program, supported by the 2008 Stand-By Arrangement, had been successful in strengthening the economy and stabilizing market conditions, while also providing lessons for macro-financial surveillance and bank support packages. Directors also recognized the positive collaboration between the European Union and the Fund during the program period. At the same time, Directors regretted that much of the fiscal achievements under the program had been unwound since the program lapsed. The recovery from the crisis has been modest and important vulnerabilities remain.

Against this background, Directors emphasized the importance of consolidating public finances, while accelerating structural reforms to support economic growth. They welcomed recent policy announcements, which aim to shore up the fiscal position and remove key structural bottlenecks in the financial sector.

Directors considered the Szell Kalman structural reform plan as a step in the right direction as it would put public debt on a declining path. While the size of the package and its emphasis on expenditures are appropriate, Directors saw scope for improving the nature of the measures. They recommended replacing levies on specific sectors, in particular on the banking sector, with more ambitious expenditure consolidation in areas such as civil service reform and the restructuring of public transport companies. Social benefits should be strictly means tested to avoid placing a disproportionate burden of adjustment on the most vulnerable. Directors 
expressed concern about the partial use of returned pension assets to finance current expenditures.

Directors noted that the lack of detail about key fiscal measures raises implementation risks. Given Hungary's high public debt and large financing needs, they emphasized the need for full and timely implementation of consolidation measures. Directors welcomed the new constitutional debt limit, but saw merit in introducing transitional rules. Ensuring the effectiveness of the new Fiscal Council will be especially important in view of its narrower mandate.

With respect to the financial sector, Directors welcomed plans to reduce stress in real estate portfolios to support a recovery in credit growth. At the same time, they cautioned that any support schemes for distressed or defaulted borrowers need to be carefully designed so as to limit moral hazard and fiscal risks. There was also concern about the gradual approach to removing foreclosure and eviction moratoria.

Directors agreed that the monetary stance is appropriate. While food prices have pushed up headline inflation, the limited recovery in domestic demand and still high unemployment point toward weak underlying price pressure.

Directors broadly agreed that a further increase in reserve coverage would provide additional insurance in the period ahead, given the considerable external amortizations in 2012-14 and ongoing tensions in the European financial markets. Banks' continued reliance on direct external funding and the foreign exchange swap market poses additional risks. Against this background, Directors expressed concern about the authorities' recent decision to draw down foreign exchange buffers to purchase a stake in the MOL energy utility.

Public Information Notices (PINs) form part of the IMF's efforts to promote transparency of the IMF's views and analysis of economic developments and policies. With the consent of the country (or countries) concerned, PINs are issued after Executive Board discussions of Article IV consultations with member countries, of its surveillance of developments at the regional level, of post-program monitoring, and of ex post assessments of member countries with longer-term program engagements. PINs are also issued after Executive Board discussions of general policy matters, unless otherwise decided by the Executive Board in a particular case. The staff report (use the free Adobe Acrobat Reader to view this pdf file) for the First Post-Program Monitoring Discussion with Hungary is also available. 
Hungary: Main Economic Indicators, 2007-12

\begin{tabular}{|c|c|c|c|c|c|c|}
\hline & 2007 & 2008 & 2009 & 2010 & 2011 & 2012 \\
\hline & & & & & \multicolumn{2}{|c|}{ Projections } \\
\hline \multicolumn{7}{|l|}{ Real economy (change in percent) } \\
\hline Real GDP & 0.8 & 0.8 & -6.7 & 1.2 & 2.6 & 2.5 \\
\hline Total domestic demand $1 /$ & -1.3 & 0.8 & -10.7 & -1.1 & 1.5 & 1.1 \\
\hline Private consumption $2 /$ & -1.7 & 0.6 & -6.8 & -2.2 & 2.0 & 1.3 \\
\hline Public Consumption 2/ & -4.2 & 0.1 & 2.2 & -0.6 & -4.0 & 0.0 \\
\hline Gross fixed investment & 1.7 & 2.9 & -8.0 & -5.6 & 1.5 & 2.0 \\
\hline Foreign balance $1 /$ & 2.1 & 0.0 & 4.0 & 2.2 & 1.1 & 1.4 \\
\hline Exports 2/ & 16.2 & 5.7 & -9.6 & 14.1 & 9.6 & 9.3 \\
\hline Imports 2/ & 13.3 & 5.8 & -14.6 & 12.0 & 9.1 & 8.5 \\
\hline CPI (end year) & 7.4 & 3.5 & 5.6 & 4.7 & 3.9 & 3.0 \\
\hline CPI (average) & 8.0 & 6.1 & 4.2 & 4.9 & 4.1 & 3.4 \\
\hline Unemployment rate (average, in percent) & 7.3 & 7.9 & 10.1 & 11.2 & 11.2 & 10.9 \\
\hline Gross domestic investment (percent of GDP) 3/ & 21.4 & 21.4 & 20.9 & 19.3 & 19.1 & 19.1 \\
\hline Gross national saving (percent of GDP, from BOP) & 14.4 & 14.1 & 21.2 & 21.4 & 20.8 & 20.7 \\
\hline \multicolumn{7}{|l|}{ General government (percent of GDP), ESA-95 basis 4/ } \\
\hline Overall balance & -5.0 & -3.6 & -4.5 & -4.2 & 2.3 & -3.3 \\
\hline Primary balance & -0.9 & 0.5 & 0.1 & -0.1 & 6.2 & 0.7 \\
\hline Primary structural balance & -1.4 & -0.8 & 1.5 & -0.3 & -0.7 & 0.3 \\
\hline Debt & 66.1 & 72.3 & 78.4 & 80.2 & 75.8 & 74.3 \\
\hline \multicolumn{7}{|l|}{ Money and credit (end-of-period, percent change) } \\
\hline Broad money & 11.0 & 8.8 & 3.4 & 3.0 & 7.1 & 9.4 \\
\hline Lending to the private sector, flow-based & 18.2 & 11.7 & -2.1 & -2.4 & 0.0 & 4.0 \\
\hline \multicolumn{7}{|l|}{ Interest rates (percent) } \\
\hline T-bill (90-day, average) & 7.6 & 8.8 & 8.4 & 5.4 & $\ldots$ & $\ldots$ \\
\hline Government bond yield (5-year, average) & 7.0 & 9.3 & 9.4 & 6.7 & $\ldots$ & $\ldots$ \\
\hline \multicolumn{7}{|l|}{ Balance of payments } \\
\hline Goods and services trade balance (percent of GDP) & 0.9 & 0.4 & 5.1 & 7.2 & 7.8 & 9.0 \\
\hline Current account (percent of GDP) & -6.9 & -7.3 & 0.4 & 2.1 & 1.7 & 1.6 \\
\hline Reserves (in billions of euros) & 16.4 & 24.0 & 30.7 & 33.5 & 38.4 & 39.2 \\
\hline Gross external debt (percent of GDP) 5/ & 103.2 & 116.0 & 146.6 & 139.8 & 139.0 & 131.0 \\
\hline \multicolumn{7}{|l|}{ Exchange rate } \\
\hline Exchange regime & \multicolumn{6}{|c|}{ Floating } \\
\hline Present rate (May 6, 2011) & \multicolumn{6}{|c|}{ Ft $182.9=$ US $\$ 1 ;$ Ft. $265.4=€ 1$} \\
\hline Nominal effective rate $(2000=100$, average $)$ & 93.7 & 93.3 & 102.6 & 102.7 & & $\ldots$ \\
\hline Real effective rate, CPI basis $(2000=100$, average $)$ & 72.6 & 70.4 & 74.8 & 72.4 & & $\ldots$ \\
\hline Quota at the Fund & \multicolumn{6}{|c|}{ SDR 1038.4 million } \\
\hline
\end{tabular}

\section{Memorandum Items}

Nominal GDP (billions of forints)

$25,321 \quad 26,754 \quad 26,054 \quad 27,120$

28,540

29,963

Sources: Hungarian authorities; IMF, International Financial Statistics; Bloomberg; and IMF staff estimates.

$1 /$ Contribution to growth. Includes change in inventories.

2/ Calculated using previous year's prices

3/ Excludes change in inventories.

4/ Consists of the central government budget, social security funds, extrabudgetary funds, and local governments. It includes the impact of the government's fiscal consolidation package announced in February 2011, as estimated by the authorities, and the transfer of Pillar two pension assets to the state.

5/ Excluding Special Purpose Entities. Including inter-company loans, and nonresident holdings of

Forint-denominated assets. 